\title{
还 \\ A EVOLUÇÃO DO CONTROLE E AVALIAÇÃO DO PLANO PLURIANUAL NO GOVERNO DO ESTADO DO PARANÁ NO PERÍODO DE 2007 A 2012: DETERMINAÇÕES E RECOMENDAÇÕES DO CONTROLE EXTERNO
}

\author{
Joanni Aparecida Henrichs \\ Mestre em Planejamento e Governança Pública pela Universidade \\ Tecnológica Federal do Paraná, Brasil. \\ E-mail: joanni3@hotmail.com \\ Márcia Beatriz Scheiner Blanski \\ Mestre em Planejamento e Governança Pública pela Universidade \\ Tecnológica Federal do Paraná, Brasil. \\ E-mail: $\underline{\text { marciablanski@brturbo.com.br }}$ \\ Antônio Gonçalves de Oliveira \\ Doutor em Engenharia de Produção pela Universidade Federal de Santa \\ Catarina, Brasil. Professor da Universidade Tecnológica Federal do Paraná, \\ Brasil. \\ E-mail: agoliveira@utfpr.edu.br
}

\begin{abstract}
Resumo
Este artigo tem por objetivo verificar o comportamento da avaliação e controle do Plano Plurianual do Governo do Estado do Paraná no período de 2007 a 2012 sob a ótica do Tribunal de Contas do Estado, a fim de conhecer como se comporta a execução orçamentária estadual frente às ações e programas traçados no Plano Plurianual. No aspecto metodológico a pesquisa é exploratória-descritiva quanto aos objetivos e consiste numa pesquisa qualitativa, pois tem como escopo visualizar o fenômeno - controle e avaliação do Plano Plurianual Estadual sob os olhos do Tribunal de Contas Estadual -, a partir da dinâmica e complexidade que lhe é intrínseca. Como resultados foi possível identificar que, mesmo a despeito das recomendações e determinações da Corte de Contas quanto à falta de efetividade do Controle Interno e a constante disparidade entre a execução orçamentária anual e o atingimento das metas e objetivos traçados no Plano, o Governo do Estado do Paraná ainda deixa de executar o Plano Plurianual nos moldes planejados e, em grande parte das vezes, o descumprimento não se encontra devidamente justificado, o que se percebe pela constante reiteração de determinações e recomendações da Corte de Contas Estadual. Conclui-se, portanto, que o descompasso entre planejamento e execução não logrou força para que o Tribunal desaprovasse qualquer das contas anuais por essa razão, o que evidencia que a falta de congruência ainda é tratada com complacência pelo controle externo.
\end{abstract}

Palavras-chave: Planejamento. Execução orçamentária. Controle. Avaliação.

\section{THE EVOLUTION OF CONTROL AND EVALUATION OF THE PLAN OF MULTIANNUAL PARANÁ STATE GOVERNMENT IN THE PERIOD OF 2007 TO 2012: FINDINGS AND RECOMMENDATIONS FOR EXTERNAL CONTROL}

\begin{abstract}
The article aims to verify the conduct of the evaluation and control of the Multi-Year Plan of the Government of the State of Paraná in the period 2007 to 2012 from the perspective of the Court of the State, in order to know how to behave in the face of state budget execution activities and programs
\end{abstract}

Perspectivas em Gestão \& Conhecimento, João Pessoa, v. 6, n. 2, p. 153-187, jul./dez. 2016. http://periodicos.ufpb.br/ojs2/index.php/pgc. ISSN: 2236-417X. Publicação sob Licença (cc) EY-NC-ND 
outlined in the Multi-Year Plan. Methodological aspect in the research is exploratory - descriptive of goals and in relation to the approach is a qualitative research, it aims to visualize the phenomenon control and evaluation of the State Multi-Year Plan under the eyes of Court of State Auditors - from the dynamics and complexity intrinsic to it. As a result, we found that, even in spite of the recommendations and decisions of the Court of Auditors regarding the lack of effectiveness of internal control and the constant disparity between the annual budget and implementing the goals and objectives outlined in the Plan, the Government of the State of Paraná still fails to execute the Multi-Year Plan in planned manner and, in most cases, the failure is not adequately justified, what is perceived by the constant reiteration of determinations and recommendations of the Court of State Auditors. Concludes, therefore, that the gap between planning and execution has been unable to force the Court disapproved of any of the annual accounts for that reason, which shows that the lack of congruence is still treated with complacency by external control.

Keywords: Planning. Budget Execution. Control. Evaluation.

\section{INTRODUÇÃO}

Tendo em vista que o planejamento no Brasil, introduzido de forma sistêmica pela Constituição de 1988, é realizado a partir de três instrumentos - Plano Plurianual (PPA), Lei de Diretrizes Orçamentárias (LDO) e Lei Orçamentária Anual (LOA) - a fim de compatibilizar metas físicas e orçamentárias, aliado ao estabelecimento recente do orçamento programa em substituição ao formato tradicional de orçamento, o qual era descompromissado com o cumprimento eficiente das ações planejadas, verificar a evolução do controle e avaliação do PPA mostra-se relevante para que se possa assentir em que medida as premissas estruturantes do planejamento governamental se confirmam ou não.

Partindo do problema que pressupõe ainda ser árduo visualizar como as ações do controle interno e externo se viabilizam na prática, o objetivo da pesquisa é verificar o comportamento da avaliação e controle do PPA do Governo do Estado do Paraná no período de 2007 a 2012 sob a ótica do Tribunal de Contas do Estado do Paraná (TCE/PR), a fim de conhecer como se comporta a execução orçamentária estadual frente às ações e programas traçados no PPA busca-se resposta à seguinte questão norteadora do estudo: as determinações e recomendações do controle externo, a partir da análise da execução do PPA, são acatadas pelo governo do Paraná?

A pesquisa se justifica ao passo que a utilização do PPA, como instrumento de planejamento, tornou-se um dos temas centrais da administração pública em todas as suas esferas, no entanto constatou-se que são incipientes os estudos que realizam a correlação entre o planejamento e o controle e avaliação, na perspectiva de sua prática, circunstância que justifica o aprofundamento sobre o tema e corrobora com a perspectiva do presente estudo que é poder contribuir teoricamente e estimular a proposição de trabalhos futuros sobre os desdobramentos que a temática proporciona.

Por relevante, frise-se que a delimitação do tema para alcançar a avaliação do PPA do Governo do Estado do Paraná no período de 2007 a 2012 se deve, em primeiro lugar, a acessibilidade aos documentos exarados pelo TCE/PR, pelo fato dos autores residirem nesse Estado, mais precisamente na Capital onde está situada a Corte de Contas e, em segundo lugar, pela motivação, em nível de Controle Social, de conhecer a quantas se comporta a execução orçamentária do Estado em que se reside frente às ações e programas traçados no PPA, já que, na condição de cidadãos, são direta e indiretamente afetados pelas políticas públicas empreendidas no Estado.

No que se refere ao lapso temporal, de um lado a limitação se faz necessária para que se possa trabalhar nos parâmetros de um artigo científico, pois a análise de todos os PPAs já elaborados no âmbito do Governo Estadual extrapolaria em muito as molduras desse recorte.

Perspectivas em Gestão \& Conhecimento, João Pessoa, v. 6, n. 2, p. 153-187, jul./dez. 2016. 
Diante disso, a escolha pelo período se deve a circunstância de que 2007-2010 compreende a gestão/mandato do último governo (PMDB) e o período de 2011 e 2012 do atual (PSDB), conduzidas por gestores (governadores) que ocupam posições opostas no palco político e, por isso mesmo, podem, como pressuposto, revelar comportamentos distintos no que se refere à execução do PPA. Ademais, no ano de 2011 houve a transição de PPAs, sendo que nesse ano o governo atual (2013) executou o orçamento à luz do PPA elaborado na gestão de seu antecessor e opositor, o que inegavelmente enriquece a pesquisa do ponto de vista político.

Frente ao objetivo, justificativa e questão norteadora deste estudo, é importante frisar que não se obstina exaurir o assunto, pois, conforme mencionado, além de serem incipientes as tratativas acadêmicas sobre a temática central - controle e avaliação do PPA - e mais germinal ainda essa análise no âmbito do Governo do Estado do Paraná, demonstrar-se-á que o assunto possui campo fecundo para inserções futuras sob os mais diversos enfoques, pois assim é a ciência na sua infinitude.

Dessa maneira, cientes das limitações em busca do objetivo proposto, este artigo estrutura-se em seis partes/seções, sendo a primeira delas esta introdução em que se sintetiza a contextualização, o problema e os objetivos do estudo. A segunda seção perfila o aporte teórico e encontra-se subdividida em duas subpartes: a primeira trata da instituição do plano plurianual, do monitoramento e avaliação e dos órgãos de controle interno e externo no Brasil, e a segunda se encarrega de abordar os aspectos teóricos referentes ao PPA Estadual, especificamente o do Estado do Paraná. A terceira seção aprofunda, respeitados seus limites espaço-temporal, os aspectos metodológicos para evidenciar o caminho percorrido pela pesquisa, enquanto que a quarta parte dedica-se em estabelecer os resultados, ou seja, verificar em que medida o TCE/PR avaliou e exerceu controle sobre o PPA do Governo Estadual. As duas partes derradeiras referem-se, respectivamente, as considerações finais e ao referencial bibliográfico que encerram e sustentam o estudo realizado.

\section{PLANO PLURIANUAL COMO FERRAMENTA DE CONTROLE E AVALIAÇÃO}

O PPA deve ser entendido como a principal ferramenta de implementação do planejamento das ações do Governo, num período de médio e longo prazo (CAVALCANTE, 2007).

Desse modo, neste aporte teórico, busca-se apresentar como se constituiu o PPA no Brasil. Não obstante, toda a riqueza histórica acerca da matéria, é retratado aqui o período mais recente, já que no país o controle e a avaliação se mostram juvenis, despontando em consequência da reforma gerencial da Administração Pública vivenciada paulatinamente ao longo dos anos.

Da lavra de Calmon e Gusso (2002), observam que no período anterior a 1990 o monitoramento, a avaliação e o controle não tinham a devida importância, especialmente em decorrência das altas taxas de inflação, que acabavam reprimindo qualquer planejamento que permitiria o controle dos resultados. Com a implantação do Plano Real, a necessidade de se criar formas de monitoramento e avaliação foram sentidas com mais urgência, culminando com a reforma gerencial desabrochada na metade da década de 1990 em diante, com destaque para aprovação do Plano Diretor de Reforma do Estado e, em 1995, a criação das bases para a implementação de uma Administração Pública voltada para resultados, defendida por parte da doutrina como sendo a Administração Pública Gerencial.

Diante desta perspectiva, na sequência são abordados os principais conceitos e tópicos referentes ao planejamento governamental brasileiro, mais especificamente com a instituição do PPA no governo do Estado do Paraná e a evolução do monitoramento e avaliação dos órgãos de controle interno e externo.

Perspectivas em Gestão \& Conhecimento, João Pessoa, v. 6, n. 2, p. 153-187, jul./dez. 2016. 


\subsection{0 plano plurianual: seu monitoramento e avaliação}

Anteriormente ao PPA houve várias tentativas de planejamento no Brasil conforme retratado por Rezende (2010), caracterizadas inicialmente pelos planos que tinham como meta a intervenção do Estado nas medidas econômicas para o desenvolvimento, como por exemplo: o Plano Salte em 1946, o Programa de Metas em 1956 e o Plano de Ação Econômica do Governo (PAEG) em 1964. A década de 70 é considerada pelo autor como o auge do planejamento com os Planos Nacionais de Desenvolvimento, que vigoraram até a metade da década de 80.

A tríade orçamentária - PPA, LDO e LOA -, foi instituída pela Constituição de 1988, em seu artigo 165. Dos três instrumentos, o PPA caracteriza-se por ser o mais abrangente, já que carrega em si o planejamento para cada quatro anos. Esse planejamento consiste no estabelecimento, de forma regionalizada, das diretrizes, dos objetivos e das metas físicas e financeiras da administração pública por meio de programas.

Os programas funcionam como o elo da integração entre os três instrumentos orçamentários, pois se o PPA se encarrega do planejamento, a LDO se ocupa em fixar as metas, prioridades e critérios para a elaboração do orçamento anual e a LOA, por seu turno, executa as ações programadas.

A integração entre planejamento e orçamento é considerada como um fator estruturante das ações governamentais, conforme se observa na afirmação de Garces e Silveira $(2002$, p. 66):

O PPA 1996-1999 introduziu o conceito de Eixos de Integração e Desenvolvimento como unidade de programação territorial e de empreendimento estruturante. O enfoque espacial inovador dos Eixos de Integração ampliou os horizontes de planejamento, introduzindo a visão estratégica de longo prazo e a identificação dos investimentos públicos e privados, para induzir o desenvolvimento em cada região.

Pelo conteúdo eminentemente programático, Assis (2012) destaca que o PPA deve ir além das metas e princípios que lhes são atribuídos por uma gestão ou governo. 0 planejamento deve ser coerente e realista, já que invariavelmente (talvez propositalmente pelo legislador constituinte) a mudança de governo não coincide com o período estipulado para a vigência do instrumento.

A primeira regulamentação atinente a elaboração e organização do PPA, da LDO e da LOA ocorreu com o Decreto 2.829/1998 (BRASIL, 1998). Para cada período foram realizados decretos subsequentes, como por exemplo, o Decreto 6.601/2008 (BRASIL, 2008).

Cavalcante (2010) relata que os primeiros PPAs brasileiros na década de 90, foram marcados por períodos de instabilidade política e econômica, bem como por dificuldades na implementação, monitoramento e avaliação, ocasionados pela desintegração organizacional entre as áreas de planejamento e orçamento ainda incipientes à época e a incompatibilidade nas linguagens e metodologias dos sistemas de planejamento e de orçamento.

No entanto, pode-se observar uma evolução com relação ao Controle e Avaliação, a partir da análise dos decretos que regulamentaram cada período do PPA, Com destaque para o modelo de gerenciamento estipulado no artigo 4 ㅇ do Decreto 2.829/1998.

O controle de prazos e custos e as normas relativas à avaliação dos resultados dos programas financiados com recursos públicos foram corroborados pela Lei Complementar $101 / 2000$ (§ 10 do art. 1ㅇ), a propalada Lei de Responsabilidade Fiscal (LRF), cujo cumprimento é obrigatório para a União, os Estados, o Distrito Federal e os Municípios, definindo e 
esclarecendo como será a fiscalização do controle de metas de resultados entre receitas e despesas.

Ainda a despeito das normatizações sobre o PPA, observa-se na Portaria MP 42/1999 (BRASIL, 1999) o estabelecimento de nova classificação (programática) que veio substituir a classificação funcional estabelecida em 1974 da seguinte forma: i) classificação funcional dividida em funções (maior nível de agregação das diversas áreas de despesa que competem ao setor público) e subfunções (participação da função, visando a agregar determinado subconjunto de despesa do setor público); ii) estrutura programática - programa, atividade, projeto e operações especiais; iii) padrão para a classificação na União, Estados e Distrito Federal a partir de 2000 e para os municípios a partir de 2002.

Com relação a utilização sistemática de indicadores e padrões de medição, verifica-se que na esfera federal foi criado um instrumento de apoio específico para o monitoramento e avaliação, por meio do Decreto 6.601/2008 (BRASIL, 2008) que estabelece o Sistema de Informações Gerenciais e de Orçamento (SIGPLAN), sob a coordenação do Ministério do Planejamento, Orçamento e Gestão, onde os órgãos do poder executivo responsáveis por programas finalísticos deverão informar a execução de suas ações por Estados e Distrito Federal e cujos resultados apurados deverão subsidiar a revisão do PPA (MPOG, 2008).

Não obstante, destaque-se que o SIGPLAN foi substituído pelo Sistema Integrado de Planejamento e Orçamento (SIOP), em janeiro de 2012.

\subsection{Os órgãos de Controle Interno e Externo}

Feitas as considerações sobre a instituição do PPA, sua finalidade e integração das suas diretrizes e metas com o orçamento, bem como a descrição das observações realizadas sobre alguns aspectos da sua evolução com relação ao monitoramento e avaliação, passa-se então a tecer considerações sobre o Controle Interno e Externo e suas atividades que impactam na avaliação dos resultados.

O controle na Administração Pública funciona como mecanismo de atenção, orientação e correção que um Poder, órgão ou autoridade exerce sobre o outro. Esta visão de controle na administração pública é ampliada por Mileski (2003), dada a observação de que o controle é corolário do Estado Democrático de Direito, ou seja, não haveria como subsistir a hipótese da inexistência do controle em defesa do direito coletivo.

$\mathrm{O}$ controle em relação ao órgão controlador se posiciona em interno ou externo. $\mathrm{Na}$ acepção de Lima (2008), tem-se por controle interno, quando o agente controlador integra a própria administração pública objeto do controle; e o controle externo representado, no Brasil, pelo Poder Legislativo, com auxílio do Tribunal de Contas.

O Controle Interno, introduzido na toada da reforma administrativa formalizada pelo Decreto-Lei 200/1967 (BRASIL, 1967), foi sedimentado formalmente pela Constituição Federal (BRASIL, 1988) em seus artigos 70 e 74, estabelecendo, dentre outros objetivos, a função de avaliar o cumprimento das metas previstas no plano plurianual, a execução dos programas de governo e dos orçamentos da União; comprovar a legalidade e avaliar os resultados quanto à eficácia e eficiência da gestão orçamentária e financeira; e apoiar o controle externo no exercício de sua missão institucional.

$\mathrm{Na}$ seara infraconstitucional as normatizações relativas ao Controle Interno vieram positivadas na Lei Federal 4.320/1964 (BRASIL, 1964), no bojo dos artigos 76 a 80; e também destacada sua importância na LRF que estabeleceu no artigo $50, \S 3^{\circ}$ a obrigatoriedade da Administração Pública instituir e manter um sistema de custos que viabilize a avaliação e o monitoramento da gestão orçamentária, financeira e patrimonial, função esta afeta ao Controle Interno. 
No âmbito do Estado do Paraná, objeto deste estudo, o Controle Interno, por simetria constitucional, encontra-se regulamentado na Constituição Estadual (PARANÁ, 1989) em seus artigos 74 e 78 com redação muito similar àquela da Carta Federal; e também na Lei Orgânica do Tribunal de Contas do Estado, a qual reservou título especial à temática, compreendendo os artigos $4^{\circ}$ a $8^{\circ}$ (PARANÁ, 2005).

O Controle Externo, por seu turno, que na dicção constitucional, é exercido pelo Congresso Nacional, com o auxílio do Tribunal de Contas, veio regulamentado no artigo 71 da Constituição Federal (BRASIL, 1988) com a finalidade de realizar a fiscalização financeira e orçamentária e julgar as contas do Chefe do Poder Executivo.

Ao Tribunal de Contas, à luz da exegese constitucional, cabe emitir parecer prévio opinando pela aprovação, aprovação com ressalvas ou desaprovação das contas do Poder Executivo, parecer este submetido posteriormente ao Poder Legislativo para ratificação ou alteração.

No âmbito do Estado do Paraná, a análise do controle externo com relação ao PPA é demonstrada nos relatórios disponibilizados pelo TCE/PR, relatórios de síntese de gestão, cadernos e os seus pareceres, com o intuito de se estabelecer a ligação entre a fiscalização dos gastos e a qualidade de sua aplicação, ou seja, os resultados da aplicação dos recursos.

Discorrido acerca da definição, atuação e responsabilidades do controle interno e externo, descreve-se a seguir como se dão as ações de avaliação do PPA pelo Controle Interno no Governo do Estado do Paraná, realizadas pelos órgãos do próprio Poder Executivo e o Controle Externo, limitado nesse artigo, consoante sua limitação geotemporal, à atuação do Tribunal de Contas Estadual.

\title{
2.2 0 controle e a avaliação do PPA no Paraná
}

Este tópico busca abordar os aspectos teóricos referente ao PPA do Estado do Paraná. Abrucio (2005, p. 412), após análise da situação das administrações públicas estaduais no Programa Nacional de Apoio à Modernização da Gestão e do Planejamento do Estado (PNAGE), conclui que o uso do PPA como instrumento de planejamento tornou-se um dos temas centrais da administração estadual, embora ainda haja que se reduzir distâncias entre o planejamento e seu respectivo controle e avaliação:

\begin{abstract}
Apesar dos avanços do PPA nos estados, três temas apareceram como problemáticos na área de planejamento. Primeiro, os estados demonstraram grande dificuldade para implantar efetivamente a gestão por programa; segundo, o planejamento não realiza, no mais das vezes, uma boa coordenação intersetorial; e, terceiro, na maioria dos governos faltam indicadores e instrumentos de avaliação. Apenas $38 \%$ dos governos estaduais utilizam efetivamente mecanismos avaliadores das políticas públicas. Disso decorre que todo o avanço da coalizão pró-PPA só terá sucesso se avançar mais em termos de avaliação dos programas (Abrucio 2005, p. 412).
\end{abstract}

No estado do Paraná, evidencia-se esta visão na análise da legislação estadual que instituiu os Planos Plurianuais, onde se observa que somente em 2011 houve alteração na legislação atinente as ações de controle e avaliação, com a inclusão de um artigo específico sobre o tema conforme a Lei 17.013/2011, art. 7.0: cabe à Secretaria de Estado do Planejamento e Coordenação Geral (SEPL) estabelecer normas complementares para a gestão, monitoramento e avaliação do PPA 2012-2015. 
Observa-se que, a partir desta normatização, foram realizadas as ações de acompanhamento do Plano Plurianual pela SEPL.

O Relatório do Acompanhamento do Plano Plurianual 2012-2015, exercício 2012, da SEPL, sintetiza a quantidade de indicadores, iniciativas e metas por cada programa finalístico, bem como o órgão responsável, conforme disciplina a tabela 1, e apresenta a execução dos Programas e Iniciativas, por meio de seus Indicadores e Metas (físicas e financeiras), respectivamente. No caso de baixa execução física, orçamentária e financeira, deverá haver justificativa e parecer acerca do seu (des)cumprimento.

Tabela 1 - Programas finalísticos - PPA 2012-2015

\begin{tabular}{|c|c|c|c|c|c|}
\hline N.으 & Programa & $\begin{array}{c}\text { Órgão } \\
\text { Responsáv } \\
\text { el } \\
\end{array}$ & $\begin{array}{l}\text { Indicad } \\
\text { ores }\end{array}$ & Iniciativas & Metas \\
\hline 01 & Acesso à Justiça & $\begin{array}{l}\text { Defensoria } \\
\text { Pública }\end{array}$ & 1 & 2 & 1 \\
\hline 02 & Desenvolvimento das Cidades & SEDU & 3 & 7 & 6 \\
\hline 03 & $\begin{array}{l}\text { Desenvolvimento Integrado da Cidadania/PDI- } \\
\text { Cidadania }\end{array}$ & SEJU & 2 & 4 & 4 \\
\hline 04 & $\begin{array}{l}\text { Desenvolvimento Rural Sustentável e } \\
\text { Abastecimento }\end{array}$ & SEAB & 1 & 23 & 18 \\
\hline 05 & Desenvolvimento Sustentável do Turismo & SETU & 2 & 5 & 5 \\
\hline 06 & Educação para Todos & SEED & 6 & 4 & 4 \\
\hline 07 & Energia & CC & 1 & 4 & 4 \\
\hline 08 & Excelência no Ensino Superior & SETI & 13 & 34 & 29 \\
\hline 09 & Inova Educação & SEED & 6 & 8 & 8 \\
\hline 10 & Morar Bem Paraná & $\mathrm{CC}$ & 2 & 5 & 4 \\
\hline 11 & Paraná Competitivo & SEIM & 1 & 5 & 5 \\
\hline 12 & Paraná Inovador & SETI & 2 & 4 & 3 \\
\hline 13 & Paraná Seguro & SESP & 1 & 22 & 21 \\
\hline 14 & Paraná Sustentável & SEMA & 2 & 16 & 16 \\
\hline 15 & Paraná tem Cultura & SEEC & 1 & 2 & 1 \\
\hline 16 & Paraná Esporte, Lazer e Atividade Física & SEED & 1 & 2 & 1 \\
\hline 17 & Proteção e Desenvolvimento Social & SEDS & 6 & 11 & 9 \\
\hline 18 & $\begin{array}{l}\text { Rede Paraná Multimodal de Transporte e } \\
\text { Logística }\end{array}$ & SEIL & 5 & 10 & 9 \\
\hline 19 & Saúde para todo Paraná & SESA & 6 & 17 & 15 \\
\hline 20 & $\begin{array}{l}\text { Trabalho, Emprego e Empreendimentos } \\
\text { Solidários }\end{array}$ & SETS & 2 & 4 & 4 \\
\hline 21 & Universalização do Saneamento Básico & $\mathrm{CC}$ & 1 & 7 & 5 \\
\hline & TOTAL & & 66 & 198 & 175 \\
\hline
\end{tabular}

Fonte: http://www.sepl.pr.gov.br.

A SEPL também instituiu o Sistema Integrado de Gestão, Avaliação e Monitoramento Estadual (SIGAME) por meio da Resolução 30/2012, publicada em 04/12/2012, em consonância com o Decreto Estadual de 17.013/2011.

Além da SEPL, o controle e a avaliação do PPA pelo Poder Executivo estadual são também realizados pela Secretaria de Controle Interno.

Não obstante a importância desse mecanismo de controle e avaliação, tal qual suscitado alhures, apenas no ano de 2007 foi instituído o Sistema de Controle Interno do Governo do Estado do Paraná, por meio da Lei Estadual 15.524/2007 (PARANÁ, 2007), sem, no entanto, guardar efetividade conforme informa os acórdãos exarados no período de 2007 a 
2012, o que levou o TCE/PR a expedir, no curso do julgamento das prestações de contas do Governo do Estado relativas aos exercícios de 2007 (Acórdão no 1133/08), 2008 (Acórdão no 800/09) e 2009 (2305/10), determinações para sua efetiva implantação.

Desta forma, tem-se que o Controle Interno do Poder Executivo do Estado do Paraná, embora instituído por lei em 2007, foi um órgão que se tornou efetivo apenas a partir de sua regulamentação no final de 2011 (Decreto 3.386/2011).

$\mathrm{Na}$ análise do Relatório do Exercício de 2011, verifica-se que o seu segundo capítulo faz a análise dos cumprimentos das metas dos instrumentos de planejamento PPA, LDO e LOA, ressaltando que a avaliação se baseou na análise dos relatórios apresentados pelas respectivas Secretarias de Governo, visto que, até então, não haviam as ferramentas necessárias para se proceder o minucioso acompanhamento (PARANÁ, 2011). O Sistema Informatizado (SIAC) somente foi implantado em 2012.

Nesse relatório resta clara a preocupação com a dificuldade de se medir as evoluções produzidas pelas ações praticadas, uma vez que estas ações estão definidas como metas, mas na realidade sem que estas estejam ligadas a um objetivo maior, não contribuindo para se medir implementação ou desempenho de políticas ou de programas governamentais.

Cita-se como exemplo o Programa Cultura Paranaense que tinha como meta aumentar em $51,86 \%$ o número de participantes em concursos culturais. Observa-se que além do efetivo desempenho ter sido menor do que o previsto, não foram identificados os reais motivos e a contribuição desta meta para a o desempenho da mencionada política.

No ano de 2012 a avaliação do Controle Interno segue realizada por meio dos Relatórios de Avaliação do SIAC dos Órgãos da Administração Direta e Autárquica, os quais compõem o Relatório do Controle Interno relativo à Prestação de Contas do exercício de 2012, conforme preconiza a Instrução Normativa 80/2012-TCE/PR,

Feito os aportes para situar como caminha a avaliação e controle do PPA no Paraná, a partir dos dados extraídos das instruções e acórdãos do TCE/PR, após os aspectos metodológicos seguintes, será realizada a análise dos resultados que complementarão o estudo, com a finalidade de descrever a avaliação do controle externo no cumprimento dos objetivos e metas do Plano Plurianual do Estado do Paraná.

\section{ASPECTOS METODOLÓGICOS}

Em relação aos aspectos metodológicos, a pesquisa é exploratória-descritiva. Para Gil (2002), a pesquisa exploratória se obstina a criar maior familiaridade com o objeto da pesquisa a fim de aprimorar ideias ou formular/intuir novas.

Desse modo, o referencial teórico buscou investigar e sistematizar o conhecimento sobre controle e avaliação do PPA e, portanto, contribuir para clarificar o problema e estabelecer prioridades a pesquisar.

Já a discussão dos resultados demandou a exploração da posição adotada pelo Tribunal de Contas do Estado do Paraná no que diz respeito ao controle e avaliação do PPA frente à execução orçamentária anual das contas do Poder Executivo do Estado do Paraná no período compreendido entre 2007 e 2012, bem como a descrição dos achados e dados contábeis.

Quanto aos meios, lançou-se mão da investigação bibliográfica e documental. Bibliográfica aplicada aos livros, teses, dissertações e artigos científicos veiculados em revistas eletrônicas para alçar o aporte teórico relacionado às temáticas de controle e avaliação do PPA e documental a partir da análise de leis federais e estaduais, bem como acórdãos e instruções exaradas pelo Tribunal de Contas do Estado do Paraná relacionados ao julgamento anual de contas do Poder Executivo Estadual.

Perspectivas em Gestão \& Conhecimento, João Pessoa, v. 6, n. 2, p. 153-187, jul./dez. 2016. 
Registre-se que os acórdãos e instruções reportados neste estudo foram acessados no sítio eletrônico da Corte de Contas Estadual.

No que se refere à abordagem, consiste então numa pesquisa qualitativa, pois busca visualizar o fenômeno - controle e avaliação do PPA Estadual sob os olhos do TCE/PR - a partir da dinâmica e complexidade que lhe é intrínseca para absorver o entendimento necessário, sem a pretensão de tomar uma proposta rigidamente estruturada, pois a intenção é estimular a proposição de estudos futuros que explorem novos enfoques (GODOY, 1995), haja vista a infinitude do conhecimento gerado pelos infinitos caminhos perseguidos pela ciência.

Por fim, ressalta-se a tendência de valorização e aceitação acadêmica quanto às pesquisas exploratório-descritivas dirigidas por meio de procedimentos bibliográficos e documentais, dada a amplitude das contribuições reveladas sobre o assunto em tela, para o qual não se justifica necessariamente a aplicação estritamente positivista que já imperou sobre os trabalhos acadêmicos em outros tempos.

\section{RESULTADOS}

Do aporte teórico foi possível identificar que o Controle Interno, introduzido na toada da reforma administrativa formalizada pelo Decreto-Lei no 200/1967, sedimentado formalmente pela Constituição Federal de 1988 (artigos 70 e 74) e acatado vastamente na legislação infraconstitucional, figura como um indispensável instrumento de acompanhamento e avaliação da gestão orçamentária, financeira e patrimonial.

A Legislação no âmbito do Estado do Paraná igualmente reverenciou esse instrumento no arcabouço constitucional estadual (artigos 74 e 78) e a Lei Complementar Estadual no 113/2005 (PARANÁ, 2005) faz expressa referencia no artigo 4으, inciso I, à competência do Controle Interno para "avaliar o cumprimento das metas previstas no Plano Plurianual, a execução de programas de governo e dos orçamentos do Estado e dos municípios".

Embora se observe sensível melhora do sistema de Controle Interno do Executivo Estadual a partir de 2010, as instruções e os acórdãos exarados nos exercícios seguintes até 2012 dão conta de evidenciar que as ressalvas, determinações e recomendações atinentes à efetividade desse controle são reiteradas ano a ano.

Nessa toada, além da fiscalização e impulso para que o Controle Interno Estadual cumpra com seu dever de controle e avaliação da gestão e, por isso mesmo, se atente a execução orçamentária anual atrelada ao que foi planejado previamente no Plano Plurianual, o TCE/PR tem se mostrado atento e proativo no que diz respeito ao cumprimento do plano de ação encartado no PPA Estadual. Esse acompanhamento decorre do artigo 29, inciso I, alínea ' $a$ ', da Lei Orgânica da Corte.

Desse modo, diante do panorama de que o Controle Interno do Governo do Estado foi instituído apenas recentemente e que não logra ainda a efetividade almejada, tal qual reiteradamente atestado pelo TCE/PR, a atenção despendida por esta Corte de Contas à análise do comportamento orçamentário anual à luz das ações programadas no Plano Plurianual é de elevada importância e será exposta, ano a ano, nos tópicos que seguem.

\subsection{Prestação de contas Estadual - Exercício financeiro de 2007}

A Assembleia Legislativa do Estado do Paraná (ALEP) encaminhou ao TCE/PR, em 05 de maio de 2008, a prestação de contas estadual referente ao exercício financeiro de 2007. 0 processo foi autuado na Corte sob o número 231180/08 e distribuído ao Conselheiro Relator. O Tribunal Pleno, por meio do Acórdão 1133/08, emitiu parecer prévio pela aprovação das contas com ressalvas.

Perspectivas em Gestão \& Conhecimento, João Pessoa, v. 6, n. 2, p. 153-187, jul./dez. 2016. 
Segundo informa a lavra do Acórdão 1133/08, o exame das contas buscou aferir a regularidade das demonstrações contábeis apuradas em 31 de dezembro de 2007, a legalidade dos atos praticados pelo Executivo estadual, bem como a eficiência dos resultados na gestão econômico-financeira, fiscal e na execução dos programas de governo.

O TCE/PR destacou a importância da avaliação de desempenho da ação governamental entabulada no PPA para a gestão pública ratificando que o controle dessa mesma ação é viabilizado por meio da mensuração de resultados dos serviços e produtos ofertados pela Administração Pública. Nesse norte, tece considerações sobre a adequação da execução orçamentária anual por meio da LOA aos objetivos fixados no PPA e na LDO. Por se tratar do último ano do PPA, mais que avaliar a execução do ano de 2007, o TCE/PR estendeu a análise para todos os anos anteriores de modo a bem contextualizar o comportamento da execução orçamentária.

O PPA 2004-2007, aprovado pela Lei Estadual 14.276/2003, estabeleceu cinco linhas bases de ação do Governo, as quais tiveram a seguinte execução ano a ano:

Tabela 2 - Execução do PPA Segundo Linhas de Ação de Governo

\begin{tabular}{|c|c|c|c|c|c|}
\hline R\$ milhão & & & & & \\
\hline DESCRIÇÃO & 2004 & 2005 & 2006 & 2007 & TOTAL \\
\hline $\begin{array}{c}\text { Educação, Inovação e } \\
\text { Cultura }\end{array}$ & $2.555,82$ & $2.799,50$ & $3.209,40$ & $3.386,09$ & $11.950,82$ \\
\hline $\begin{array}{c}\text { Infraestrutura e Meio } \\
\text { Ambiente }\end{array}$ & 589,73 & 730,68 & 827,07 & 414,19 & $2.561,67$ \\
\hline Expansão Produtiva & 392,59 & 408,16 & 260,05 & 234,95 & $1.295,75$ \\
\hline $\begin{array}{l}\text { Emprego, Cidadania e } \\
\text { Solidariedade }\end{array}$ & $2.344,40$ & $2.805,07$ & $3.278,70$ & $3.145,36$ & $11.573,53$ \\
\hline Gestão do Estado & $7.590,20$ & $8.429,08$ & $8.586,79$ & $8.773,82$ & $33.379,89$ \\
\hline TOTAL & $13.472,73$ & $15.172,50$ & $16.162,02$ & $15.954,41$ & $60.761,66$ \\
\hline
\end{tabular}

Fonte: Acórdão 1133/08 - TCE/PR

Constata-se da análise da tabela 2 que no decorrer da execução do PPA foi crescente a aplicação de recursos no período de 2004-2006, representando uma variação de $19,96 \%$. Já no exercício de 2007, em comparação com 2006, houve o decréscimo de $1,28 \%$ na aplicação total de recursos, motivados pelas reduções de aplicações de $50 \%$ na linha de Infraestrutura e Meio Ambiente, 10\% de Expansão Produtiva e de 4,06\% em Emprego, Cidadania e Solidariedade.

Não obstante a variação horizontal, de modo geral, em cada linha de ação houve uma manutenção aproximada da distribuição vertical de recursos ao longo dos anos, merecendo destaque o fato de que, cumulativamente as maiores aplicações de recursos (55\%) foram destinadas à manutenção da máquina estatal (linha Gestão do Estado), 20\% foram destinados à Educação, Inovação e Cultura, 4\% em Infraestrutura e Meio Ambiente, 2\% em Expansão Produtiva e 19\% Emprego, Cidadania e Solidariedade.

Pontualmente em relação à execução de 2007, os investimentos nos programas de governo se comportaram à luz do exposto na Tabela 3.

Tabela 3 - Execução física do orçamento-programa - Programas de Governo 2007 (Em R\$ mil)

\begin{tabular}{|c|c|c|c|c|c|}
\hline $\begin{array}{c}\text { Programas de } \\
\text { Governo }\end{array}$ & $\begin{array}{l}\text { Autorizado final } \\
\text { (1) }\end{array}$ & $\begin{array}{c}\text { AV \% } \\
\text { S/TOTAL }\end{array}$ & Realizado (2) & $\begin{array}{c}\text { AV \% } \\
\text { S/TOTAL }\end{array}$ & $\begin{array}{c}\mathrm{AH} \% \\
2 / 1\end{array}$ \\
\hline Obrigações Especiais & 7.810 .767 & $43,49 \%$ & 7.066 .330 & $42,29 \%$ & $90,47 \%$ \\
\hline Educação & 2.714 .904 & $15,12 \%$ & 2.562.149 & $16,06 \%$ & $94,37 \%$ \\
\hline Saúde & 1.848 .980 & $10,29 \%$ & 1.665 .352 & $10,44 \%$ & $90,07 \%$ \\
\hline Segurança Cidadã & 1.169 .754 & $6,51 \%$ & 1.035 .063 & $6,49 \%$ & $88,49 \%$ \\
\hline Desenvolvimento do & 898.000 & $5,00 \%$ & 764.691 & $4,79 \%$ & $85,15 \%$ \\
\hline
\end{tabular}




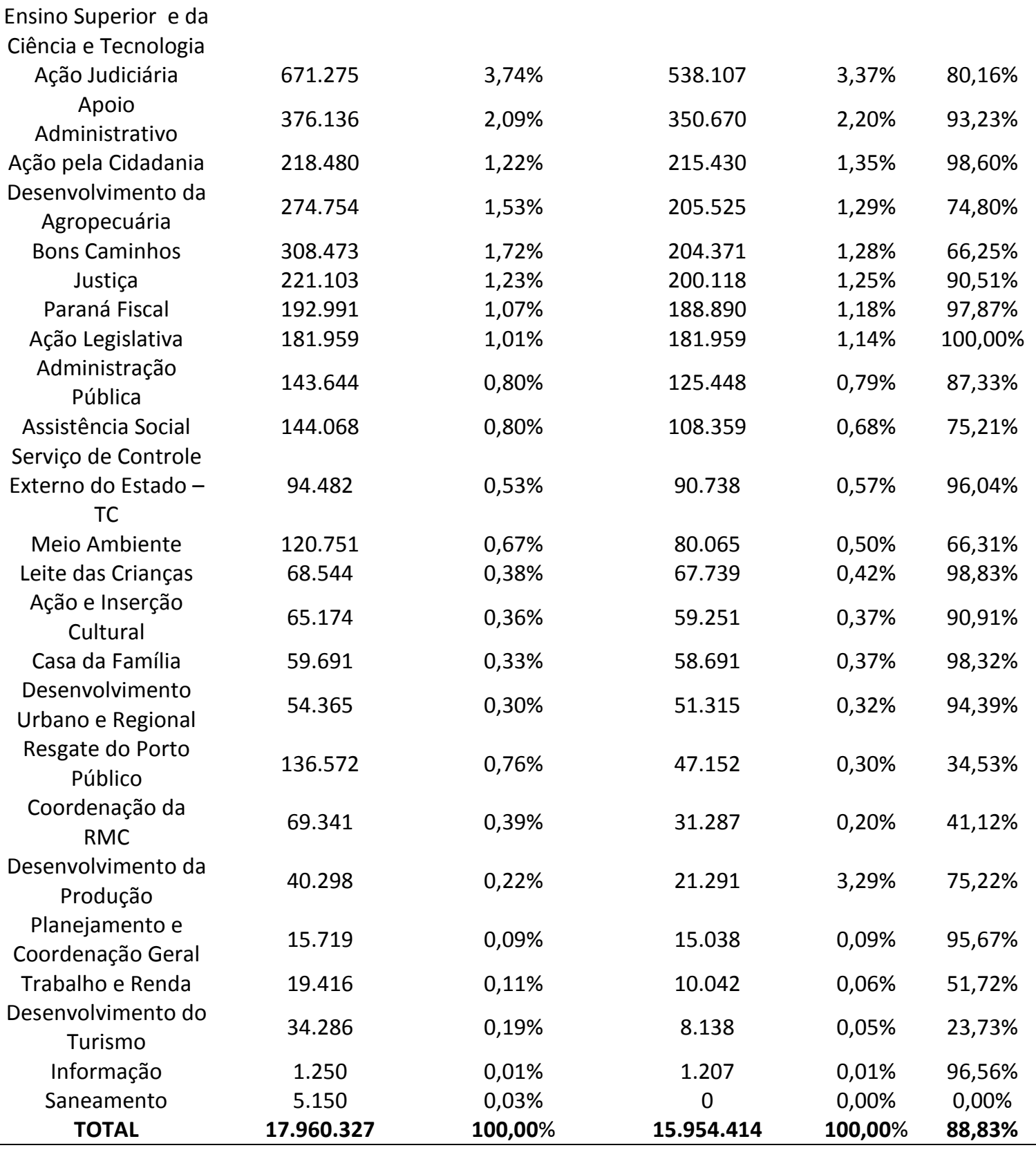

Fontes: Lei 15.757/07 (PPA), Lei 15.609/07 (LDO), Lei 15.750/07 (LOA) e dados adaptados a partir da Instrução 53/2008 da Diretoria de Contas Estaduais extraída dos autos físicos 231180/08 - TCE/PR

A Diretoria de Contas Estaduais do TCE/PR, por meio da Instrução 53/2008, adentrou na execução dos programas de governo e, de modo geral, pontuou que os projetos e atividades realizadas pelo Governo do Estado no ano de 2007 caminharam de acordo com as ações propostas no PPA e também guardaram unicidade aos objetivos dos Programas propostos na LDO.

Houve, entrementes, apontamentos referentes ao não cumprimento de duas metas prefixadas e com despesas aprovadas pela LDO: Projeto de Gestão do SUS e os programas de Saneamento e Programa Energia no exercício de 2007.

No decorrer do processo foi oportunizado contraditório e a Secretaria de Estado do Planejamento e Coordenação Geral (SEPL) informou, com relação aos programas de Saneamento e Programa Energia, que estes têm sua execução nos "Orçamento de 
Investimento das Empresas Públicas e Sociedade de Economia Mista, aparecendo no Orçamento Fiscal apenas os recursos a serem integralizados pelo Tesouro Geral do Estado" (Acórdão 1133/08, p. 67) e que tais programas foram executados pela Companhia Paranaense de Saneamento (SANEPAR) e Companhia Paranaense de Energia (COPEL) com recursos próprios.

A justificativa foi considerada satisfatória pela Diretoria de Contas Estaduais (DCE) e, por conseguinte, pelos Conselheiros no momento do julgamento plenário. Já no que se refere à Gestão do SUS, não houve qualquer justificativa por parte do Estado.

Nas conclusões derradeiras do acórdão são apontadas diversas ressalvas e recomendações, dentre as quais, pela pertinência ao recorte que aqui se propõe, se destaca a recomendação encaminhada à Inspetoria de Controle Externo atinente a ausência de efetividade do Sistema de Controle Interno (responsável primário por avaliar o cumprimento das metas previstas no Plano Plurianual).

\subsection{Prestação de contas Estadual - Exercício financeiro de 2008}

No que se refere à prestação de contas relativa ao exercício de 2008, a Assembleia Legislativa do Estado do Paraná (ALEP) encaminhou o procedimento ao TCE/PR, o qual foi autuado na Corte sob o número 179832/09 e distribuído ao Conselheiro Relator. O Tribunal Pleno, por meio do Acórdão 800/09, emitiu por unanimidade parecer prévio pela aprovação das contas com ressalvas.

Em seu voto, o relator destacou no acórdão 800/2009 que a preocupação do TCE/PR na análise da execução orçamentária, financeira e contábil foi além da mera observância dos preceitos de lei e repousou, sobretudo, na visualização do resultado das ações sob o prisma do benefício produzido à sociedade a partir de um exame apurado dos resultados qualitativos dos programas de governo.

Nesse particular, o PPA 2008-2011, aprovado pela Lei Estadual 15.757/2007, constituiu-se em três linhas de ação que se desdobraram em vinte e quatro programas ${ }^{1}$, e o total orçamentário aprovado pela LOA comportou-se da seguinte forma:

Tabela 4 - Comparativo do Orçamento 2008 - PPA x LOA

R\$ milhão

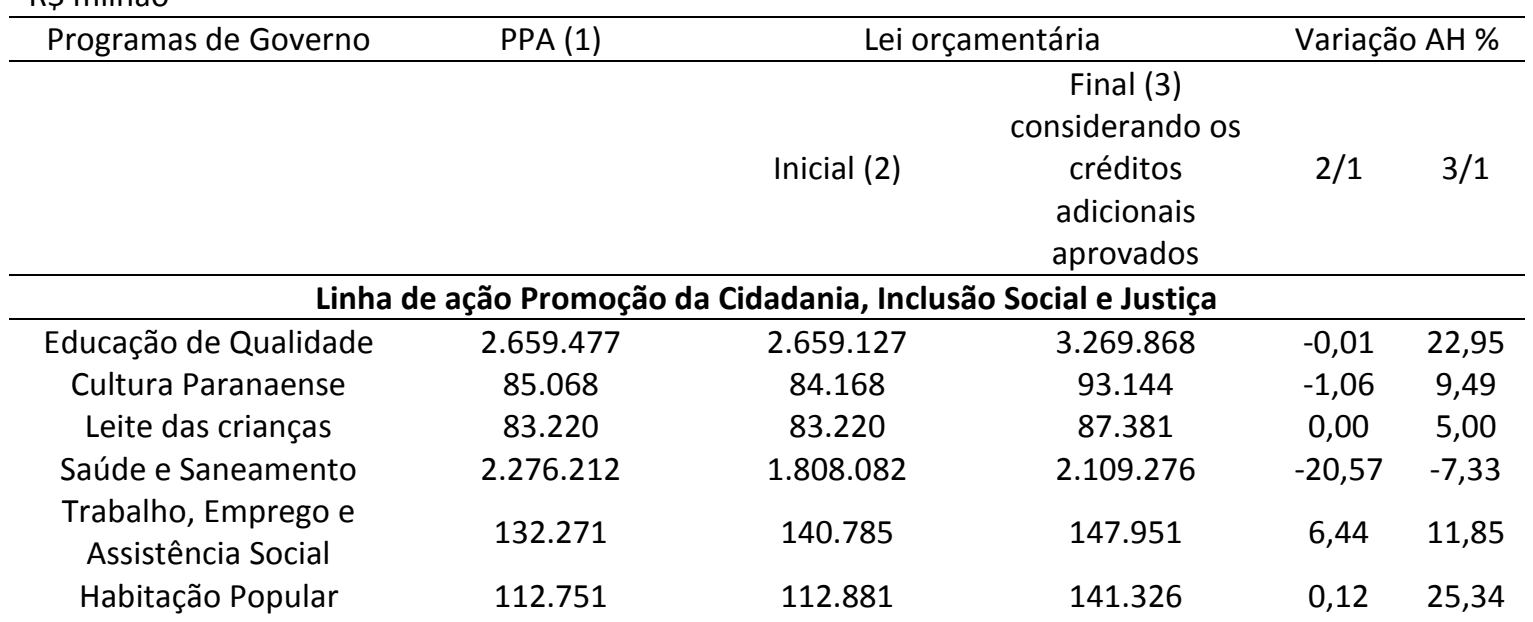

\footnotetext{
${ }^{1}$ Segundo informa o acórdão 800/09 e a própria lei que aprovou o PPA, desse universo de programas, quatro dizem respeito à responsabilidade de outros Poderes e um pertencente ao Governo Federal, ou seja, de caráter não orçamentário incluído apenas para acompanhamento (Programa de Aceleração do Crescimento e Desenvolvimento do Paraná - PAC).
} 


\begin{tabular}{|c|c|c|c|c|c|}
\hline Segurança Integrada & 1.239 .938 & 1.241.128 & 1.344.338 & 0,10 & 8,42 \\
\hline $\begin{array}{c}\text { Promoção da Justiça e } \\
\text { Cidadania }\end{array}$ & 296.318 & 296.368 & 286.878 & 0,02 & $-3,19$ \\
\hline $\begin{array}{c}\text { Proteção à Criança e a } \\
\text { Juventude }\end{array}$ & 109.764 & 111.729 & 156.200 & 1,79 & 42,31 \\
\hline \multicolumn{6}{|c|}{ Linha de ação Desenvolvimento Econômico Sustentável e Descentralizado } \\
\hline Ensino Superior e & & & & & \\
\hline $\begin{array}{l}\text { Desenvolvimento } \\
\text { Científico-Tecnológico }\end{array}$ & 948.816 & 948.716 & 1.098.126 & 0,01 & 15,74 \\
\hline $\begin{array}{c}\text { Transporte Integrado e } \\
\text { Logística }\end{array}$ & 552.626 & 542.084 & 563.185 & $-1,91$ & 1,91 \\
\hline \multicolumn{6}{|l|}{ Preservação Ambiental e } \\
\hline $\begin{array}{c}\text { Gestão de Recursos } \\
\text { Hídricos }\end{array}$ & 133.389 & 132.904 & 145.002 & $-0,36$ & 8,71 \\
\hline Desenvolvimento & & & & & \\
\hline $\begin{array}{c}\text { Regional e } \\
\text { Metropolitano }\end{array}$ & 106.400 & 112.910 & 89.455 & 6,12 & 15,93 \\
\hline \multicolumn{6}{|l|}{$\begin{array}{l}\text { Metropolitano } \\
\text { Diversificação }\end{array}$} \\
\hline $\begin{array}{l}\text { Agropecuária e } \\
\text { Fortalecimento do }\end{array}$ & 284.375 & 289.284 & 318.900 & 1,73 & 12,14 \\
\hline \multicolumn{6}{|l|}{ Agronegócio Familiar } \\
\hline $\begin{array}{l}\text { Desenvolvimento da } \\
\text { Produção }\end{array}$ & 59.460 & 55.508 & 48.042 & $-6,65$ & $\begin{array}{c}- \\
19,20\end{array}$ \\
\hline Turismo, Esporte e Lazer & 61.229 & 61.510 & 42.316 & 0,46 & $\begin{array}{c}- \\
30,89\end{array}$ \\
\hline \multicolumn{6}{|c|}{ Linha de ação Gestão Pública Transparente e Integrada } \\
\hline $\begin{array}{c}\text { Gestão do Estado } \\
\text { Apoio e }\end{array}$ & 523.995 & 484.516 & 538.820 & $-7,53$ & 2,83 \\
\hline $\begin{array}{l}\text { Desenvolvimento do } \\
\text { Ministério Público }\end{array}$ & 194.876 & 207.405 & 253.751 & 6,43 & 30,21 \\
\hline Ação Legislativa & 179.349 & 196.349 & 241.399 & 9,48 & 34,60 \\
\hline $\begin{array}{c}\text { Controle Externo ao } \\
\text { Estado }\end{array}$ & 99.320 & 99.320 & 104.642 & 0,00 & 5,36 \\
\hline Ação Judiciária & 598.005 & 597.907 & 757.174 & $-0,02$ & 26,62 \\
\hline $\begin{array}{c}\text { Valorização e } \\
\text { Capacitação do Servidor } \\
\text { Público }\end{array}$ & 2.107 & 2.107 & 1.351 & 0,00 & $\begin{array}{c}- \\
35,88\end{array}$ \\
\hline Obrigações Especiais & 8.510 .336 & 8.462 .103 & 8.290 .928 & $-0,57$ & $-2,58$ \\
\hline TOTAL & 19.249.304 & 18.730 .111 & 20.129 .453 & $-2,70$ & 4,57 \\
\hline
\end{tabular}

Nota: Não está incluído o valor do Orçamento de Investimento das Empresas Públicas e Sociedades de Economia Mista Dependentes.

Fontes: Lei 15.609/07 (LDO), Lei 15.750/07 (LOA) e Acórdão 800/09 - TCE/PR

A partir dos dados apurados, o TCE/PR observa-se que o orçamento final (compreendido os créditos adicionais) autorizado na LOA apresentou um acréscimo de 4,57\% em comparação ao que foi previsto no PPA.

De outro lado, às metas previstas para o exercício de 2008 no orçamento-programa e realizadas nesse período, foram dispostas conforme se vê na Tabela 5:

Tabela 5 - Execução do orçamento-programa - Programas de Governo 2008 (Em R\$ mil)

\begin{tabular}{cccccc}
$\begin{array}{c}\text { Programas de } \\
\text { Governo }\end{array}$ & $\begin{array}{c}\text { Autorizado final } \\
(1)\end{array}$ & $\begin{array}{c}\text { AV \% } \\
\text { S/TOTAL }\end{array}$ & Realizado (2) & $\begin{array}{c}\text { AV \% } \\
\text { S/TOTAL }\end{array}$ & $\begin{array}{c}\text { AH \% } \\
2 / 1\end{array}$ \\
\hline Promoção da & $\mathbf{7 . 6 3 6 . 3 6 2}$ & $\mathbf{3 7 , 9 4 \%}$ & $\mathbf{6 . 8 4 7 . 7 3 5}$ & $\mathbf{3 7 , 3 6 \%}$ & $\mathbf{8 9 , 6 7 \%}$ \\
\hline
\end{tabular}

Perspectivas em Gestão \& Conhecimento, João Pessoa, v. 6, n. 2, p. 153-187, jul./dez. 2016. 


\begin{tabular}{|c|c|c|c|c|c|}
\hline \multicolumn{6}{|l|}{$\begin{array}{l}\text { Cidadania, Inclusão } \\
\text { Social e Justiça }\end{array}$} \\
\hline $\begin{array}{c}\text { Educação de } \\
\text { Qualidade }\end{array}$ & 3.269 .868 & $16,24 \%$ & 3.071 .918 & $16,76 \%$ & $93,95 \%$ \\
\hline Cultura Paranaense & 93.144 & $0,46 \%$ & 77.058 & $0,42 \%$ & $82,73 \%$ \\
\hline Leite das crianças & 87.381 & $0,43 \%$ & 81.873 & $0,45 \%$ & $93,70 \%$ \\
\hline Saúde e Saneamento & 2.109 .276 & $10,48 \%$ & 1.912 .838 & $10,44 \%$ & $90,69 \%$ \\
\hline $\begin{array}{l}\text { Trabalho, Emprego e } \\
\text { Assistência Social }\end{array}$ & 147.951 & $0,73 \%$ & 113.879 & $0,62 \%$ & $76,97 \%$ \\
\hline Habitação Popular & 141.326 & $0,70 \%$ & 89.242 & $0,49 \%$ & $63,15 \%$ \\
\hline Segurança Integrada & 1.344 .338 & $6,68 \%$ & 1.151 .022 & $6,28 \%$ & $85,62 \%$ \\
\hline $\begin{array}{l}\text { Promoção da Justiça } \\
\text { e Cidadania }\end{array}$ & 286.878 & $1,43 \%$ & 240.318 & $1,31 \%$ & $83,77 \%$ \\
\hline $\begin{array}{c}\text { Proteção à Criança e } \\
\text { a Juventude }\end{array}$ & 156.200 & $0,78 \%$ & 109.587 & $0,60 \%$ & $70,16 \%$ \\
\hline $\begin{array}{c}\text { Linha de ação } \\
\text { Desenvolvimento } \\
\text { Econômico } \\
\text { Sustentável e } \\
\text { Descentralizado } \\
\end{array}$ & 2.305 .025 & $11,45 \%$ & 1.840 .214 & $10,04 \%$ & $79,83 \%$ \\
\hline $\begin{array}{c}\text { Ensino Superior e } \\
\text { Desenvolvimento } \\
\text { Científico- } \\
\text { Tecnológico }\end{array}$ & 1.098 .126 & $5,46 \%$ & 961.103 & $5,24 \%$ & $87,52 \%$ \\
\hline $\begin{array}{l}\text { Transporte } \\
\text { Integrado e Logística } \\
\text { Preservação }\end{array}$ & 563.185 & $2,80 \%$ & 422.930 & $2,31 \%$ & $75,10 \%$ \\
\hline $\begin{array}{l}\text { Ambiental e Gestão } \\
\text { de Recursos Hídricos } \\
\text { Desenvolvimento }\end{array}$ & 145.002 & $0,72 \%$ & 88.351 & $0,48 \%$ & $60,93 \%$ \\
\hline $\begin{array}{l}\text { Regional e } \\
\text { Metropolitano } \\
\text { Diversificação }\end{array}$ & 89.455 & $0,44 \%$ & 79.219 & $0,43 \%$ & $88,56 \%$ \\
\hline $\begin{array}{c}\text { Agropecuária e } \\
\text { Fortalecimento do } \\
\text { Agronegócio Familiar }\end{array}$ & 318.900 & $1,58 \%$ & 241.300 & $1,32 \%$ & $75,67 \%$ \\
\hline $\begin{array}{l}\text { Desenvolvimento da } \\
\text { Produção }\end{array}$ & 48.042 & $0,24 \%$ & 27.885 & $0,15 \%$ & $58,04 \%$ \\
\hline $\begin{array}{c}\text { Turismo, Esporte e } \\
\text { Lazer }\end{array}$ & 42.316 & $0,21 \%$ & 19.426 & $0,11 \%$ & $45,91 \%$ \\
\hline $\begin{array}{l}\text { Linha de ação } \\
\text { Gestão Pública } \\
\text { Transparente e } \\
\text { Integrada }\end{array}$ & 1.897 .137 & $9,42 \%$ & 1.655 .095 & $9,03 \%$ & $87,24 \%$ \\
\hline $\begin{array}{c}\text { Gestão do Estado } \\
\text { Apoio e }\end{array}$ & 538.820 & $2,68 \%$ & 456.649 & $2,49 \%$ & $84,75 \%$ \\
\hline $\begin{array}{l}\text { Desenvolvimento do } \\
\text { Ministério Público }\end{array}$ & 253.751 & $1,26 \%$ & 249.804 & $1,36 \%$ & $98,44 \%$ \\
\hline Ação Legislativa & 241.399 & $1,20 \%$ & 229.887 & $1,25 \%$ & $95,23 \%$ \\
\hline $\begin{array}{c}\text { Controle Externo ao } \\
\text { Estado }\end{array}$ & 104.642 & $0,52 \%$ & 103.920 & $0,57 \%$ & $99,31 \%$ \\
\hline Ação Judiciária & 757.174 & $3,76 \%$ & 613.715 & $3,35 \%$ & $81,05 \%$ \\
\hline $\begin{array}{l}\text { Valorização e } \\
\text { Capacitação do }\end{array}$ & 1.351 & $0,01 \%$ & 1.119 & $0,01 \%$ & $82,85 \%$ \\
\hline
\end{tabular}

Perspectivas em Gestão \& Conhecimento, João Pessoa, v. 6, n. 2, p. 153-187, jul./dez. 2016. 
Servidor Público

\begin{tabular}{cccccc}
\hline Obrigações Especiais & $\mathbf{8 . 2 9 0 . 9 2 8}$ & $41,19 \%$ & $\mathbf{7 . 9 8 6 . 0 6 1}$ & $\mathbf{4 3 , 5 7 \%}$ & $\mathbf{9 6 , 3 2 \%}$ \\
\hline TOTAL & $\mathbf{2 0 . 1 2 9 . 4 5 3}$ & $100,00 \%$ & 18.329 .104 & $100,00 \%$ & $91,06 \%$ \\
\hline
\end{tabular}

Fontes: Lei 15.757/07 (PPA), Lei 15.609/07 (LDO) e Lei 15.750/07 (LOA)

Fonte: Adaptado do Acórdão 800/09 - TCE/PR

Os dados demonstram que no exercício de 2008 realizou-se $91,06 \%$ do orçamento autorizado para execução dos programas de governo delimitados no PPA.

Destaque-se que para a análise da execução do PPA 2008-2011, o TCE/PR estabeleceu mecanismos para avaliar a qualidade das metas realizadas, o que se convencionou chamar indicadores de desempenho, circunstância inédita até então, haja vista que os PPAs anteriores não dispunham desse instrumento.

Entrementes, no curso da prestação de contas a Secretaria de Estado do Planejamento e Coordenação Geral (SEPL) informou que até o mês de Junho de 2008 o Estado não havia apurado os índices alcançados naquele mesmo ano para os indicadores inseridos no PPA. Justificou ainda que alguns indicadores mereciam ajustes, pois não permitiam a adequada medição do alcance dos objetivos dos programas e que em apenas um ano os resultados decorrentes da implantação dos indicadores careciam de maturação para viabilizar a avaliação.

Desse modo, o olhar do TCE/PR a esses indicadores de desempenho e seus respectivos impactos restou prejudicado conforme se depreende de excerto do Acórdão 800/2009 (p. 108): "a avaliação anual do Plano Plurianual, que deveria servir para informar sobre os resultados atingidos, bem como subsidiar a elaboração da Lei de Diretrizes Orçamentárias, alterar o Plano Plurianual e a Lei Orçamentária Anual, na prática não se viabilizou".

Nas conclusões finais o TCE/PR reiterou a determinação ao Governo Estadual para que adotasse medidas adequadas para implantação efetiva do sistema de controle interno e recomendou à Secretaria de Estado do Planejamento e Coordenação Geral (SEPL) que procedesse a avaliação do PPA previamente à elaboração da Lei Orçamentária Anual para os próximos exercícios financeiros, independentemente da qualidade dos indicadores.

\subsection{Prestação de contas Estadual - Exercício financeiro de 2009}

Como rito processual, a Assembleia Legislativa do Estado do Paraná (ALEP) encaminhou ao TCE/PR, em 19 de abril de 2010, a prestação de contas estadual referente ao exercício financeiro de 2009. O processo foi autuado sob o número 210543/10 e distribuído ao Conselheiro Relator. O Tribunal Pleno, por meio do Acórdão 2305/10, emitiu, por maioria absoluta, parecer prévio pela aprovação das contas com ressalvas.

A exemplo dos anos anteriores, o relator das contas ressalta no acórdão a ausência de efetividade do controle interno, isso porque os mecanismos existentes à época eram insuficientes para efetivar o controle da forma devida e não se dispunha de uma rotina sistematizada de compartilhamento das informações, repercutindo, dentre outras circunstâncias, na inacessibilidade das informações pelo controle externo.

A par disso, o TCE/PR apresentou, conforme tabela 6, o seguinte comparativo entre o que foi previsto para os Programas de Governo no PPA (PARANÁ, 2007) e o que foi efetivamente contemplado na LOA para o exercício de 2009:

Tabela 6 - Comparativo do Orçamento 2009 - PPA x LOA (R\$ milhão)

\begin{tabular}{cccc} 
Programas de Governo & LPA (1) & Lei orçamentária & Variação AH \% \\
\hline Inicial (2) & $\begin{array}{c}\text { Final (3) } \\
\text { considerando os } \\
\text { créditos }\end{array}$ & $2 / 1$ & $3 / 1$ \\
\hline
\end{tabular}

Perspectivas em Gestão \& Conhecimento, João Pessoa, v. 6, n. 2, p. 153-187, jul./dez. 2016. 


\begin{tabular}{|c|c|c|c|c|c|}
\hline & & \multicolumn{4}{|c|}{$\begin{array}{l}\text { adicionais } \\
\text { aprovados }\end{array}$} \\
\hline \multicolumn{6}{|c|}{ Linha de ação Promoção da Cidadania, Inclusão Social e Justiça } \\
\hline Educação de Qualidade & 2.888 .757 & 3.347 .828 & 3.446 .243 & 15,89 & 19,30 \\
\hline Cultura Paranaense & 75.674 & 103.839 & 147.988 & 37,22 & 95,56 \\
\hline Leite das crianças & 86.938 & 85.191 & 82.343 & $-2,01$ & $-5,29$ \\
\hline Saúde e Saneamento & 2.213 .007 & 2.146 .755 & 2.269 .063 & $-2,99$ & 2,53 \\
\hline $\begin{array}{l}\text { Trabalho, Emprego e } \\
\text { Assistência Social }\end{array}$ & 150.706 & 147.672 & 133.945 & $-2,01$ & 11,12 \\
\hline Habitação Popular & 90.262 & 160.234 & 166.917 & 77,52 & 84,93 \\
\hline Segurança Integrada & 1.300 .117 & 1.590 .298 & 1.408 .164 & 22,32 & 8,31 \\
\hline $\begin{array}{c}\text { Promoção da Justiça e } \\
\text { Cidadania }\end{array}$ & 301.653 & 300.819 & 277.130 & $-0,28$ & $-8,13$ \\
\hline $\begin{array}{c}\text { Proteção à Criança e a } \\
\text { Juventude }\end{array}$ & 113.130 & 140.883 & 215.112 & 24,53 & 90,15 \\
\hline \multicolumn{6}{|c|}{ Linha de ação Desenvolvimento Econômico Sustentável e Descentralizado } \\
\hline Ensino Superior e & & & & & \\
\hline Desenvolvimento & 990.632 & 1.201 .069 & 1.263 .903 & 21,24 & 27,59 \\
\hline Científico-Tecnológico & & & & & \\
\hline $\begin{array}{c}\text { Transporte Integrado e } \\
\text { Logística }\end{array}$ & 582.282 & 605.996 & 803.119 & 4,07 & 37,93 \\
\hline \multicolumn{6}{|l|}{ Preservação Ambiental e } \\
\hline $\begin{array}{c}\text { Gestão de Recursos } \\
\text { Hídricos }\end{array}$ & 148.939 & 171.089 & 182.303 & 14,87 & 22,40 \\
\hline Desenvolvimento & & & & & \\
\hline $\begin{array}{l}\text { Regional e } \\
\text { Metropolitano }\end{array}$ & 108.582 & 113.498 & 122.509 & 4,53 & 12,83 \\
\hline $\begin{array}{c}\text { Diversificação } \\
\text { Agropecuária e } \\
\text { Fortalecimento do } \\
\text { Agronegócio Familiar }\end{array}$ & 331.602 & 248.078 & 251.208 & $-25,19$ & $\begin{array}{c}- \\
24,24\end{array}$ \\
\hline $\begin{array}{l}\text { Desenvolvimento da } \\
\text { Produção }\end{array}$ & 57.844 & 42.279 & 43.003 & $-26,91$ & $\begin{array}{c}- \\
25,66\end{array}$ \\
\hline Turismo, Esporte e Lazer & 97.390 & 80.432 & 78.743 & $-17,41$ & $\begin{array}{c}- \\
19,15\end{array}$ \\
\hline \multicolumn{6}{|c|}{ Linha de ação Gestão Pública Transparente e Integrada } \\
\hline $\begin{array}{c}\text { Gestão do Estado } \\
\text { Apoio e }\end{array}$ & 521.481 & 535.684 & 545.247 & 2,72 & 4,56 \\
\hline $\begin{array}{l}\text { Desenvolvimento do } \\
\text { Ministério Público }\end{array}$ & 205.813 & 285.018 & 278.329 & 38,48 & 35,23 \\
\hline Ação Legislativa & 196.076 & 265.397 & 264.620 & 35,35 & 34,96 \\
\hline $\begin{array}{c}\text { Controle Externo ao } \\
\text { Estado }\end{array}$ & 100.633 & 118.593 & 118.693 & 17,85 & 17,95 \\
\hline $\begin{array}{l}\text { Ação Judiciária } \\
\text { Valorização e }\end{array}$ & 651.372 & 749.038 & 861.742 & 14,99 & 32,30 \\
\hline $\begin{array}{c}\text { Capacitação do Servidor } \\
\text { Público }\end{array}$ & 2.138 & 2.514 & 2.232 & 17,54 & 4,39 \\
\hline Obrigações Especiais & 7.789 .907 & 9.695 .752 & 9.600 .874 & 24,47 & 23,25 \\
\hline TOTAL & 19.004 .937 & 22.137.954 & 22.563 .429 & 16,49 & 18,72 \\
\hline
\end{tabular}

Nota: Não está incluído o valor do Orçamento de Investimento das Empresas Públicas e Sociedades de Economia Mista Dependentes.

Fontes: Fontes Lei 15.917/08 (LDO) e Lei 16.032/08 (LOA) e dados adaptados da Instrução 56/2010 da Diretoria de Contas Estaduais extraída dos autos físicos 210543/10 - TCE/PR 
O referencial da tabela 6 , em análise, mostra que o orçamento final autorizado na LOA superou em $18,72 \%$ o valor previsto no PPA. Ciente da importância dos programas de governo, visto que são os elos entre o PPA e o orçamento, a exemplo do ano anterior o TCE/PR ilustrou os valores orçados e realizados dentro das linhas de ação, conforme mostra a Tabela 7:

Tabela 7 - Execução física do orçamento-programa - Programas de Governo 2009 (Em R\$ mil)

\begin{tabular}{|c|c|c|c|c|c|}
\hline $\begin{array}{c}\text { Programas de } \\
\text { Governo }\end{array}$ & $\begin{array}{c}\text { Autorizado final } \\
(1)\end{array}$ & $\begin{array}{c}\text { AV \% } \\
\text { S/TOTAL }\end{array}$ & Realizado (2) & $\begin{array}{c}\text { AV \% } \\
\text { S/TOTAL }\end{array}$ & $\begin{array}{c}\mathrm{AH} \% \\
2 / 1\end{array}$ \\
\hline $\begin{array}{c}\text { Promoção da } \\
\text { Cidadania, Inclusão } \\
\text { Social e Justiça }\end{array}$ & 8.146 .906 & $36,11 \%$ & 7.361 .362 & $37,37 \%$ & $90,36 \%$ \\
\hline $\begin{array}{c}\text { Educação de } \\
\text { Qualidade }\end{array}$ & 3.446 .243 & $15,27 \%$ & 3.266 .842 & $16,59 \%$ & $94,79 \%$ \\
\hline Cultura Paranaense & 147.988 & $0,66 \%$ & 116.246 & $0,59 \%$ & $78,55 \%$ \\
\hline Leite das crianças & 82.343 & $0,36 \%$ & 57.370 & $0,29 \%$ & $69,67 \%$ \\
\hline Saúde e Saneamento & 2.269 .063 & $10,06 \%$ & 2.075 .913 & $10,54 \%$ & $91,49 \%$ \\
\hline $\begin{array}{l}\text { Trabalho, Emprego e } \\
\text { Assistência Social }\end{array}$ & 133.945 & $0,59 \%$ & 102.216 & $0,52 \%$ & $76,31 \%$ \\
\hline Habitação Popular & 166.917 & $0,74 \%$ & 115.817 & $0,59 \%$ & $63,39 \%$ \\
\hline Segurança Integrada & 1.408 .164 & $6,24 \%$ & 1.199 .588 & $6,09 \%$ & $85,19 \%$ \\
\hline $\begin{array}{c}\text { Promoção da Justiça } \\
\text { e Cidadania }\end{array}$ & 277.130 & $1,23 \%$ & 252.100 & $1,28 \%$ & $90,97 \%$ \\
\hline $\begin{array}{c}\text { Proteção à Criança e } \\
\text { a Juventude }\end{array}$ & 215.112 & $0,95 \%$ & 175.269 & $0,89 \%$ & $81,48 \%$ \\
\hline $\begin{array}{c}\text { Linha de ação } \\
\text { Desenvolvimento } \\
\text { Econômico } \\
\text { Sustentável e } \\
\text { Descentralizado }\end{array}$ & 2.744.787 & $12,16 \%$ & 2.128.181 & $10,80 \%$ & $77,54 \%$ \\
\hline $\begin{array}{c}\text { Ensino Superior e } \\
\text { Desenvolvimento } \\
\text { Científico- } \\
\text { Tecnológico }\end{array}$ & 1.263 .903 & $5,60 \%$ & 1.111 .656 & $5,64 \%$ & $87,95 \%$ \\
\hline $\begin{array}{c}\text { Transporte } \\
\text { Integrado e Logística } \\
\text { Preservação }\end{array}$ & 803.119 & $3,56 \%$ & 571.525 & $2,90 \%$ & $71.16 \%$ \\
\hline $\begin{array}{c}\text { Ambiental e Gestão } \\
\text { de Recursos Hídricos } \\
\text { Desenvolvimento }\end{array}$ & 182.303 & $0,81 \%$ & 100.163 & $0,51 \%$ & $54,94 \%$ \\
\hline $\begin{array}{c}\text { Regional e } \\
\text { Metropolitano } \\
\text { Diversificação }\end{array}$ & 122.509 & $0,54 \%$ & 88.067 & $0,45 \%$ & $71,89 \%$ \\
\hline $\begin{array}{l}\text { Agropecuária e } \\
\text { Fortalecimento do } \\
\text { Agronegócio Familiar }\end{array}$ & 251.208 & $1,11 \%$ & 207.318 & $1,05 \%$ & $82,53 \%$ \\
\hline $\begin{array}{l}\text { Desenvolvimento da } \\
\text { Produção }\end{array}$ & 43.003 & $0,19 \%$ & 28.381 & $0,14 \%$ & $66,00 \%$ \\
\hline $\begin{array}{c}\text { Turismo, Esporte e } \\
\text { Lazer }\end{array}$ & 78.743 & $0,35 \%$ & 21.070 & $0,11 \%$ & $27,76 \%$ \\
\hline $\begin{array}{c}\text { Linha de ação } \\
\text { Gestão Pública } \\
\text { Transparente e } \\
\text { Integrada }\end{array}$ & 2.070 .862 & $9,18 \%$ & 1.724 .341 & $8,75 \%$ & $83,27 \%$ \\
\hline Gestão do Estado & 545.247 & $2,42 \%$ & 459.780 & $2,33 \%$ & $84,33 \%$ \\
\hline
\end{tabular}

Perspectivas em Gestão \& Conhecimento, João Pessoa, v. 6, n. 2, p. 153-187, jul./dez. 2016. 


\begin{tabular}{|c|c|c|c|c|c|}
\hline Apoio e & & & & & \\
\hline $\begin{array}{l}\text { Desenvolvimento do } \\
\text { Ministério Público }\end{array}$ & 278.329 & $1,23 \%$ & 266.362 & $1,35 \%$ & $95,70 \%$ \\
\hline Ação Legislativa & 264.620 & $1,17 \%$ & 248.310 & $1,26 \%$ & $93,84 \%$ \\
\hline $\begin{array}{c}\text { Controle Externo ao } \\
\text { Estado }\end{array}$ & 118.693 & $0,53 \%$ & 100.706 & $0,51 \%$ & $84,85 \%$ \\
\hline $\begin{array}{l}\text { Ação Judiciária } \\
\text { Valorização e }\end{array}$ & 861.742 & $3,82 \%$ & 648.174 & $3,29 \%$ & $75,22 \%$ \\
\hline $\begin{array}{l}\text { Capacitação do } \\
\text { Servidor Público }\end{array}$ & 2.232 & $0,01 \%$ & 1.009 & $0,01 \%$ & $45,22 \%$ \\
\hline Obrigações Especiais & 9.600 .874 & $42,55 \%$ & 8.482 .820 & $43,07 \%$ & $88,35 \%$ \\
\hline TOTAL & 22.563 .429 & $100,00 \%$ & 19.696.704 & $100,00 \%$ & $87,29 \%$ \\
\hline
\end{tabular}

Fontes: Lei 15.757/07 (PPA), Lei 15.917/08 (LDO) e Lei 16.032/08 (LOA) e dados adaptados da Instrução 56/2010 da Diretoria de Contas Estaduais extraída dos autos físicos 210543/10 - TCE/PR

Embora no exercício de 2009 tenha se aplicado 19,7 bilhões nos programas de governo, ou seja, quase um bilhão a mais em comparação com o ano anterior ( 18,3 bilhões), a realização do orçamento autorizado para execução dos programas de governo delineados no PPA nesse exercício $(87,29 \%)$ foi menor do que a do exercício de $2008(91,06 \%)$.

O TCE/PR observou que os programas Obrigações Especiais $(43,07 \%)$, Educação de Qualidade (16,59\%), Saúde e Saneamento (10,54\%), Segurança Integrada (6,09\%) e Ensino Superior e Desenvolvimento Científico-Tecnológico $(5,64 \%)$ tiveram os maiores percentuais de realização diante do total realizado. Os demais programas corresponderam a $18,07 \%$ do total realizado.

Diante do panorama que se apresentou no exercício de 2009, o TCE/PR exarou as seguintes determinações e recomendações ao Estado do Paraná pertinentes ao objeto deste estudo:

Quadro 1 - Determinações e Recomendações

\begin{tabular}{|c|c|}
\hline Determinações & Recomendações \\
\hline $\begin{array}{l}\text { - Governo do Estado - Elaborar o Plano Plurianual, } \\
2012 \text { a } 2015 \text {, de maneira que todos os programas } \\
\text { sejam providos de metas e indicadores capazes de } \\
\text { medir o desempenho, o que restou ausente no } \\
\text { plano de } 2004 \text { a } 2007 \text { e em alguns programas do } \\
\text { PPA 2008-2011, conforme artigo } 165 \text { da } \\
\text { Constituição Federal. } \\
\text { - Governo do Estado - Apresentar na prestação de } \\
\text { contas, relatórios gerenciais de acompanhamento } \\
\text { das metas físicas, sincronizados com o } \\
\text { estabelecido no PPA e justificativas quanto ao não } \\
\text { cumprimento de ações ou metas estabelecidas na } \\
\text { LOA. } \\
\text { - Governo do Estado - Implantar o sistema de } \\
\text { controle interno, consoante dispõe a Lei } \\
\text { 15.524/2007 e o Decreto 955/2007. }\end{array}$ & $\begin{array}{l}\text { - Implementar relatórios de acompanhamento } \\
\text { anuais do PPA, demonstrando o desempenho } \\
\text { entre as metas previstas em relação as realizadas, } \\
\text { disponibilizando-os em meio eletrônico, para } \\
\text { garantia do cumprimento do Princípio da } \\
\text { Transparência. } \\
\text { - Implementar melhorias nos instrumentos } \\
\text { oriundos do PPA (LDO - LOA), no sentido de } \\
\text { possibilitar a sincronia de linguagem visando a } \\
\text { rápida e fácil identificação dos programas ações } \\
\text { ou metas em todas as fases do seu ciclo: } \\
\text { planejamento, execução, controle e, } \\
\text { principalmente, prestação de contas aos órgãos } \\
\text { de controle e à sociedade. } \\
\text { - Na gestão de pessoas: Elaborar o planejamento } \\
\text { das políticas de gestão de pessoas, alinhadas ao } \\
\text { PPA. }\end{array}$ \\
\hline
\end{tabular}

Fonte: Dados adaptados do acórdão 2305/10 - TCE/PR

As determinações e recomendações revelam a persistente inefetividade do controle interno estadual e a necessária melhoria do diálogo entre PPA e LOA, para que a execução orçamentária alie-se ao que foi planejado. 


\subsection{Prestação de contas Estadual - Exercício financeiro de 2010}

A prestação de contas estadual referente ao exercício financeiro de 2010 foi encaminhada ao TCE/PR pela Assembleia Legislativa do Estado do Paraná (ALEP) em 01 de junho de 2010, cujo processo foi autuado na Corte sob o número 327290/11 e distribuído ao Conselheiro Relator. O Tribunal Pleno, por meio do Acórdão 176/11, emitiu, por maioria absoluta parecer prévio pela aprovação das contas com ressalvas.

A Diretoria de Contas Estaduais do TCE/PR consignou na Instrução 80/2011 que as metas e prioridades do Governo do Estado, contempladas na LDO de 2010, convergem com aquelas fixadas no PPA 2008-2011. Nesse viés, a previsão de orçamento dos Programas de Governo estabelecido no PPA teve o seguinte comportamento na LOA como mostrado na Tabela 8:

Tabela 8 - Comparativo do Orçamento 2010 - PPA x LOA (R\$ milhão)

\begin{tabular}{|c|c|c|c|c|c|}
\hline \multirow[t]{2}{*}{$\begin{array}{c}\text { Programas de } \\
\text { Governo } \\
\end{array}$} & \multirow[t]{2}{*}{ PPA (1) } & \multicolumn{2}{|c|}{ Lei orçamentária } & \multicolumn{2}{|c|}{ Variação AH \% } \\
\hline & & Inicial (2) & $\begin{array}{c}\text { Final (3) } \\
\text { considerando os } \\
\text { créditos adicionais } \\
\text { aprovados }\end{array}$ & $2 / 1$ & $3 / 1$ \\
\hline \multicolumn{6}{|c|}{ Linha de ação Promoção da Cidadania, Inclusão Social e Justiça } \\
\hline $\begin{array}{c}\text { Educação de } \\
\text { Qualidade }\end{array}$ & 3.086 .356 & 3.550 .963 & 3.894 .126 & 15,05 & 26,17 \\
\hline Cultura Paranaense & 81.035 & 82.310 & 106.620 & 1,57 & 31,57 \\
\hline Leite das crianças & 90.454 & 85.010 & 85.010 & $-6,02$ & $-6,02$ \\
\hline $\begin{array}{c}\text { Saúde e } \\
\text { Saneamento }\end{array}$ & 2.180 .876 & 2.466 .962 & 2.564 .296 & 13,12 & 17,58 \\
\hline $\begin{array}{c}\text { Trabalho, Emprego e } \\
\text { Assistência Social }\end{array}$ & 165.668 & 137.290 & 140.882 & $-17,13$ & $-14,96$ \\
\hline Habitação Popular & 100.859 & 196.731 & 168.181 & 95,06 & 66,75 \\
\hline Segurança Integrada & 1.360 .842 & 1.512 .638 & 1.606 .723 & 11,15 & 18,07 \\
\hline $\begin{array}{c}\text { Promoção da Justiça } \\
\text { e Cidadania }\end{array}$ & 293.417 & 311.543 & 311.151 & 6,18 & 6,04 \\
\hline $\begin{array}{c}\text { Proteção à Criança e } \\
\text { a Juventude }\end{array}$ & 116.874 & 162.983 & 187.644 & 39,45 & 60,55 \\
\hline
\end{tabular}

Linha de ação Desenvolvimento Econômico Sustentável e Descentralizado

\begin{tabular}{|c|c|c|c|c|c|}
\hline \multicolumn{6}{|l|}{ Ensino Superior e } \\
\hline $\begin{array}{l}\text { Desenvolvimento } \\
\text { Científico- } \\
\text { Tecnológico }\end{array}$ & 1.063 .062 & 1.298 .404 & 1.376 .304 & 22,14 & 29,47 \\
\hline $\begin{array}{l}\text { Transporte } \\
\text { Integrado e Logística } \\
\text { Preservação }\end{array}$ & 629.595 & 614.658 & 929.795 & $-2,37$ & 47,68 \\
\hline $\begin{array}{l}\text { Ambiental e Gestão } \\
\text { de Recursos Hídricos }\end{array}$ & 168.475 & 147.370 & 215.329 & $-12,53$ & 27,81 \\
\hline $\begin{array}{l}\text { Desenvolvimento } \\
\text { Regional e }\end{array}$ & 61.378 & 156.299 & 341.019 & 154,65 & 455,61 \\
\hline $\begin{array}{l}\text { Metropolitano } \\
\text { Diversificação }\end{array}$ & & & & & \\
\hline $\begin{array}{l}\text { Agropecuária e } \\
\text { Fortalecimento do } \\
\text { Agronegócio }\end{array}$ & 349.035 & 288.740 & 309.006 & $-17,27$ & $-11,47$ \\
\hline
\end{tabular}

Perspectivas em Gestão \& Conhecimento, João Pessoa, v. 6, n. 2, p. 153-187, jul./dez. 2016. 
Familiar

\begin{tabular}{|c|c|c|c|c|c|}
\hline $\begin{array}{l}\text { Desenvolvimento da } \\
\text { Produção }\end{array}$ & 49.768 & 47.619 & 48.278 & $-4,32$ & $-2,99$ \\
\hline $\begin{array}{c}\text { Turismo, Esporte e } \\
\text { Lazer }\end{array}$ & 100.328 & 84.080 & 67.739 & $-16,19$ & $-32,48$ \\
\hline \multicolumn{6}{|c|}{ Linha de ação Gestão Pública Transparente e Integrada } \\
\hline $\begin{array}{c}\text { Gestão do Estado } \\
\text { Apoio e }\end{array}$ & 540.598 & 533.706 & 592.547 & $-1,27$ & 9,61 \\
\hline $\begin{array}{l}\text { Desenvolvimento do } \\
\text { Ministério Público }\end{array}$ & 226.983 & 314.293 & 311.052 & 38,52 & 37,09 \\
\hline Ação Legislativa & 210.413 & 249.277 & 248.852 & 20,58 & 26,88 \\
\hline $\begin{array}{c}\text { Controle Externo ao } \\
\text { Estado }\end{array}$ & 106.247 & 128.115 & 134.807 & 20,58 & 26,88 \\
\hline $\begin{array}{l}\text { Ação Judiciária } \\
\text { Valorização e }\end{array}$ & 744.729 & 799.092 & 925.002 & 7,30 & 24,21 \\
\hline $\begin{array}{l}\text { Capacitação do } \\
\text { Servidor Público }\end{array}$ & 2.189 & 3.312 & 2.996 & 51,28 & 36,89 \\
\hline Obrigações Especiais & 8.111 .713 & 10.405 .952 & 9.587 .240 & 28,28 & 18.19 \\
\hline TOTAL & 20.704.303.840,00 & 23.577.381.540,00 & 24.154.724.671,00 & 13,88 & 16,67 \\
\hline
\end{tabular}

Nota: Não está incluído o valor do Orçamento de Investimento das Empresas Públicas e Sociedades de Economia Mista Dependentes.

Fontes: Adaptado da Instrução 80/2011 da Diretoria de Contas Estaduais extraída dos autos 327290/11 TCE/PR e Leis 16.193/09 (LDO) e 16.369/09 (LOA)

Seguindo o mesmo raciocínio empregado até então, observa-se que a inteligência da análise da tabela 8 mostra que o orçamento final autorizado na LOA-2010 superou 16,67\% em relação ao previsto no PPA, percentual pouco inferior aquele apresentado em 2009 (18,72\%) e muito superior se comparado a 2008 (4,57\%).

No que concerne às respectivas linhas de ação dos Programas de Governo, os valores orçados e realizados restaram dispostos nos termos que seguem na Tabela 9.

Tabela 9 - Execução física do orçamento-programa - Programas de Governo 2010 (Em R\$ mi)

\begin{tabular}{|c|c|c|c|c|c|}
\hline $\begin{array}{c}\text { Programas de } \\
\text { Governo }\end{array}$ & $\begin{array}{c}\text { Autorizado final } \\
(1)\end{array}$ & $\begin{array}{c}\text { AV \% } \\
\text { S/TOTAL }\end{array}$ & Realizado (2) & $\begin{array}{c}\text { AH \% } \\
\text { S/TOTAL }\end{array}$ & $\begin{array}{c}\mathrm{AH} \% \\
2 / 1 \\
\end{array}$ \\
\hline \multicolumn{6}{|l|}{ Promoção da } \\
\hline $\begin{array}{l}\text { Cidadania, Inclusão } \\
\text { Social e Justiça }\end{array}$ & 9.052 .508 & $34,48 \%$ & 8.342 .617 & $37,62 \%$ & $92,16 \%$ \\
\hline $\begin{array}{l}\text { Educação de } \\
\text { Qualidade }\end{array}$ & 3.894 .126 & $16,12 \%$ & 3.769 .603 & $16,96 \%$ & $96,57 \%$ \\
\hline Cultura Paranaense & 106.620 & $0,44 \%$ & 91.925 & $0,41 \%$ & $86,22 \%$ \\
\hline Leite das crianças & 85.010 & $0,35 \%$ & 67.800 & $0,31 \%$ & $79,75 \%$ \\
\hline Saúde e Saneamento & 2.552 .172 & $10,57 \%$ & 2.345 .574 & $10,58 \%$ & $91,91 \%$ \\
\hline $\begin{array}{l}\text { Trabalho, Emprego e } \\
\text { Assistência Social }\end{array}$ & 140.882 & $0,58 \%$ & 87.679 & $0,40 \%$ & $62,24 \%$ \\
\hline Habitação Popular & 168.181 & $0,70 \%$ & 149.345 & $0,67 \%$ & $88,80 \%$ \\
\hline Segurança Integrada & 1.606 .723 & $6,65 \%$ & 1.397 .465 & $6,30 \%$ & $86,98 \%$ \\
\hline $\begin{array}{c}\text { Promoção da Justiça } \\
\text { e Cidadania }\end{array}$ & 311.151 & $1,29 \%$ & 302.432 & $1,36 \%$ & $97,20 \%$ \\
\hline $\begin{array}{c}\text { Proteção à Criança e } \\
\text { a Juventude }\end{array}$ & 187.644 & $0,78 \%$ & 139.794 & $0,63 \%$ & $74,50 \%$ \\
\hline $\begin{array}{c}\text { Linha de ação } \\
\text { Desenvolvimento } \\
\text { Econômico }\end{array}$ & 3.287 .596 & $13,61 \%$ & 2.704 .775 & $12,20 \%$ & $82,27 \%$ \\
\hline
\end{tabular}

Perspectivas em Gestão \& Conhecimento, João Pessoa, v. 6, n. 2, p. 153-187, jul./dez. 2016. 


\begin{tabular}{|c|c|c|c|c|c|}
\hline \multicolumn{6}{|l|}{$\begin{array}{c}\text { Sustentável e } \\
\text { Descentralizado }\end{array}$} \\
\hline Ensino Superior e & & & & & \\
\hline $\begin{array}{l}\text { Desenvolvimento } \\
\text { Científico- } \\
\text { Tecnológico }\end{array}$ & 1.376 .394 & $5,70 \%$ & 1.234 .366 & $5,57 \%$ & $89,68 \%$ \\
\hline $\begin{array}{l}\text { Transporte } \\
\text { Integrado e Logística } \\
\text { Preservação }\end{array}$ & 929.795 & $3,85 \%$ & 792.899 & $3,58 \%$ & $85,28 \%$ \\
\hline $\begin{array}{l}\text { Ambiental e Gestão } \\
\text { de Recursos Hídricos }\end{array}$ & 215.329 & $0,89 \%$ & 130.156 & $0,59 \%$ & $60,45 \%$ \\
\hline $\begin{array}{l}\text { Desenvolvimento } \\
\text { Regional e } \\
\text { Metropolitano } \\
\text { Diversificacão }\end{array}$ & 341.019 & $1,41 \%$ & 263.471 & $1,19 \%$ & $77,26 \%$ \\
\hline $\begin{array}{l}\text { Agropecuária e } \\
\text { Fortalecimento do } \\
\text { Agronegócio Familiar }\end{array}$ & 309.006 & $1,28 \%$ & 225.407 & $1,02 \%$ & $72,95 \%$ \\
\hline $\begin{array}{l}\text { Desenvolvimento da } \\
\text { Produção }\end{array}$ & 48.278 & $0,20 \%$ & 31.774 & $0,14 \%$ & $65,82 \%$ \\
\hline $\begin{array}{c}\text { Turismo, Esporte e } \\
\text { Lazer }\end{array}$ & 67.739 & $0,28 \%$ & 26.702 & $0,12 \%$ & $39,42 \%$ \\
\hline $\begin{array}{l}\text { Linha de ação } \\
\text { Gestão Pública } \\
\text { Transparente e } \\
\text { Integrada }\end{array}$ & 2.215 .257 & $9,17 \%$ & 1.940 .782 & $8,75 \%$ & $87,61 \%$ \\
\hline $\begin{array}{l}\text { Gestão do Estado } \\
\text { Apoio e }\end{array}$ & 592.547 & $2,45 \%$ & 537.942 & $2,43 \%$ & $90,78 \%$ \\
\hline $\begin{array}{l}\text { Desenvolvimento do } \\
\text { Ministério Público }\end{array}$ & 311.052 & $1,29 \%$ & 296.430 & $1,34 \%$ & $95,30 \%$ \\
\hline Ação Legislativa & 248.852 & $1,03 \%$ & 238.201 & $1,07 \%$ & $95,72 \%$ \\
\hline $\begin{array}{c}\text { Controle Externo ao } \\
\text { Estado }\end{array}$ & 134.807 & $0,56 \%$ & 118.324 & $0,53 \%$ & $87,77 \%$ \\
\hline $\begin{array}{l}\text { Ação Judiciária } \\
\text { Valorização e }\end{array}$ & 925.002 & $3,83 \%$ & 748.740 & $3,38 \%$ & $80,94 \%$ \\
\hline $\begin{array}{l}\text { Capacitação do } \\
\text { Servidor Público }\end{array}$ & 2.996 & $0,01 \%$ & 1.145 & $0,01 \%$ & $38,22 \%$ \\
\hline Obrigações Especiais & 9.599 .365 & $39,74 \%$ & 9.189 .159 & $41,43 \%$ & $95,73 \%$ \\
\hline TOTAL & 24.154.725 & $100,00 \%$ & 22.177.333 & $100,00 \%$ & $91,81 \%$ \\
\hline
\end{tabular}

Fontes: Adaptado da Instrução 80/2011 da Diretoria de Contas Estaduais extraída dos autos 327290/11 TCE/PR; Lei 15.757/07 (PPA), Lei 16.193/09 (LDO) e Lei 16.369/09 (LOA)

O percentual de realização das metas previstas no PPA $(91,81 \%)$ superou os dois anos anteriores: (87,29\%) em 2009 e em 2008 (91,06\%).

Em consonância com o ano anterior, os programas Obrigações Especiais (41,43\%), Educação de Qualidade (16,96\%), Saúde e Saneamento (10,58\%), Segurança Integrada (6,30\%) e Ensino Superior e Desenvolvimento Científico-Tecnológico (5,57\%) representaram juntos 80,84\% da realização do orçamento do Estado em 2010.

Feita a análise, o TCE/PR apontou no acórdão 176/11 como ressalva à aprovação das contas o fato do Controle Interno do Governo do Estado ter sido pouco efetivo quanto à execução dos ditames legais sobre a matéria, o que teria resultado em prejuízo ao planejamento e controle dos atos de governo. 
$\mathrm{Na}$ sequencia, o acórdão reitera duas determinações que foram expedidas no ano anterior. A primeira no sentido de determinar que o Governo do Estado elabore o PPA 20122015 de forma que todos os programas possuam metas e indicadores para medir o desempenho; e a segunda, com relação a metas físicas, para que o Governo apresente na prestação de contas relatórios de acompanhamento devidamente sincronizados com o PPA e, na hipótese de não cumprimento das metas e ações estabelecidas, constem justificativas do não atendimento.

As recomendações foram reiteradas na íntegra daquelas apresentadas no ano anterior, nos termos do Quadro 1.

\subsection{Prestação de contas Estadual - Exercício financeiro de 2011}

A prestação de contas estadual referente ao exercício financeiro de 2011 foi encaminhada ao TCE/PR pela Assembleia Legislativa do Estado do Paraná (ALEP) em 03 de abril de 2012, cujo processo foi autuado sob o número 296372/12 e distribuído ao Conselheiro Relator. O Tribunal Pleno, por meio do Acórdão 290/12, emitiu, por unanimidade, parecer prévio pela aprovação das contas com ressalvas.

Frise-se que o exercício de 2011 guarda particularidades em razão de ser o último ano do PPA 2008-2011 elaborado sob a égide do Governo anterior (2007-2010) e executado (realizado) no primeiro ano do mandato do atual governo (2011- 2014).

A Instrução 92/2012 da Diretoria de Contas Estaduais do TCE/PR levantou o comparativo entre o que foi previsto no PPA e o que foi contemplado na LOA para o exercício de 2011, conforme segue na Tabela 10:

Tabela 10 - Comparativo do Orçamento 2011 - PPA x LOA (R\$ milhão)

Programas de Governo PPA (1) Lei orçamentária

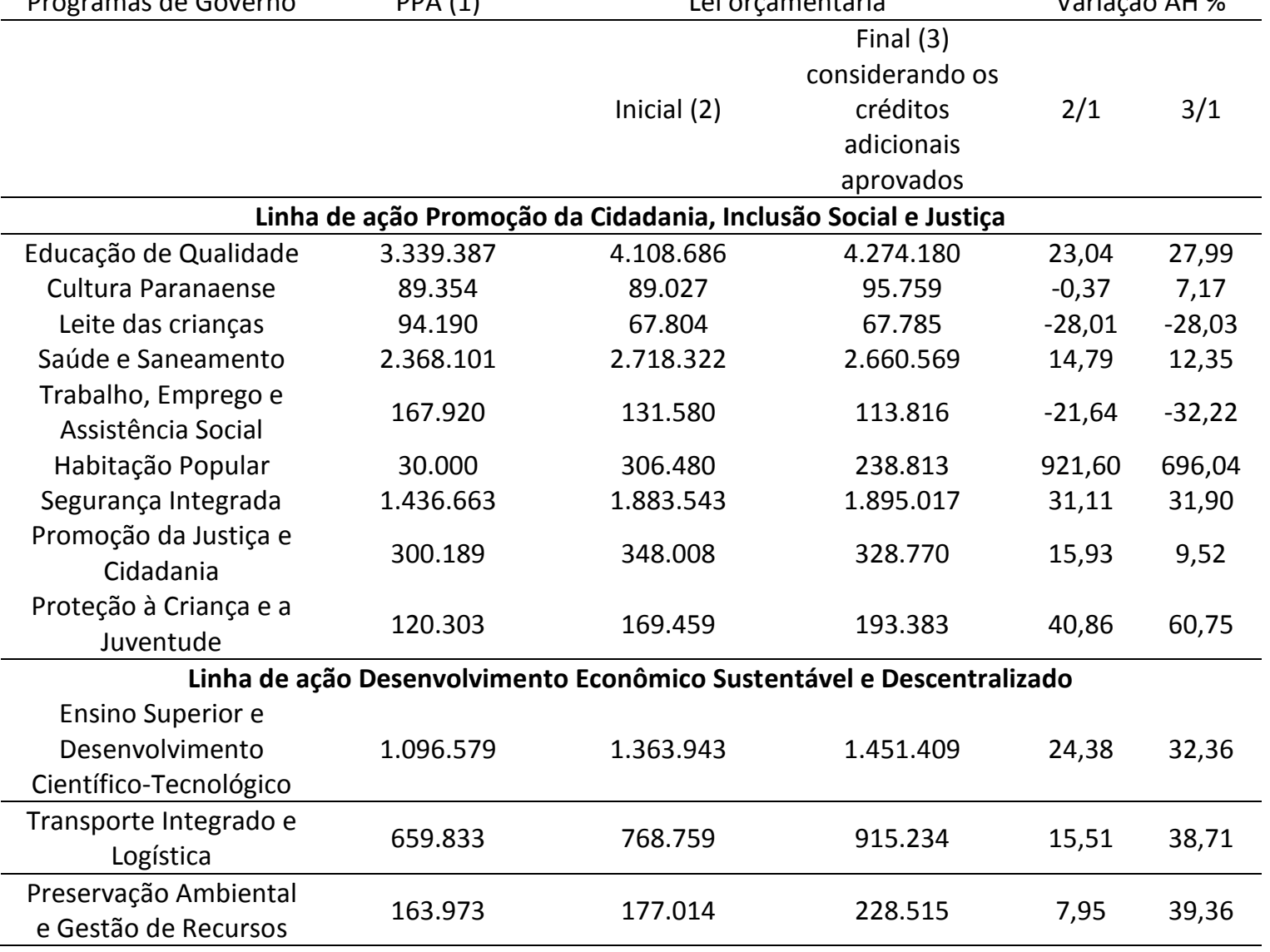

Variação $\mathrm{AH} \%$

Perspectivas em Gestão \& Conhecimento, João Pessoa, v. 6, n. 2, p. 153-187, jul./dez. 2016. 


\begin{tabular}{|c|c|c|c|c|c|}
\hline \multicolumn{6}{|l|}{ Hídricos } \\
\hline Desenvolvimento & \multirow{3}{*}{44.267} & \multirow{3}{*}{183.487} & \multirow{3}{*}{101.408} & \multirow{3}{*}{314,50} & \multirow{3}{*}{129,08} \\
\hline Regional e & & & & & \\
\hline Metropolitano & & & & & \\
\hline Diversificação & \multirow{4}{*}{336.105} & \multirow{4}{*}{314.334} & \multirow{4}{*}{349.406} & \multirow{4}{*}{$-6,48$} & \multirow{4}{*}{3,96} \\
\hline Agropecuária e & & & & & \\
\hline Fortalecimento do & & & & & \\
\hline Agronegócio Familiar & & & & & \\
\hline $\begin{array}{l}\text { Desenvolvimento da } \\
\text { Produção }\end{array}$ & 47.977 & 46.764 & 46.163 & $-2,53$ & $-3,78$ \\
\hline Turismo, Esporte e Lazer & 95.256 & 67.046 & 39.982 & $-29,61$ & $-58,03$ \\
\hline \multicolumn{6}{|c|}{ Linha de ação Gestão Pública Transparente e Integrada } \\
\hline $\begin{array}{c}\text { Gestão do Estado } \\
\text { Apoio e }\end{array}$ & 549.584 & 569.512 & 682.568 & 3,63 & 24,20 \\
\hline \multicolumn{5}{|l|}{ Ministério Público } & 62,20 \\
\hline Ação Legislativa & 225.111 & 259.349 & 259.349 & 15,21 & 15,21 \\
\hline $\begin{array}{c}\text { Controle Externo ao } \\
\text { Estado }\end{array}$ & 112.692 & 146.331 & 178.557 & 29,85 & 58,45 \\
\hline Ação Judiciária & 809.330 & 1.042 .591 & 1.302 .347 & 28,82 & 60,92 \\
\hline \multicolumn{6}{|l|}{ Valorização e } \\
\hline \multicolumn{6}{|l|}{ Público } \\
\hline Obrigações Especiais & 8.751 .826 & 10.146 .032 & 10.606.144 & 15,93 & 21,19 \\
\hline TOTAL & 21.089 .490 & 25.303 .415 & 26.433 .315 & 19,98 & 25,34 \\
\hline
\end{tabular}

Nota: Não está incluído o valor do Orçamento de Investimento das Empresas Públicas e Sociedades de Economia Mista Dependentes.

Fonte: Adaptado da Instrução 92/2012 da Diretoria de Contas Estaduais extraída dos autos 296372/12 TCE/PR; Lei 16.561/10 (LDO) e Lei 16.739/10 (LOA)

O acréscimo de valores na LOA, em relação ao planejamento inicial do PPA, alcançou $25,34 \%$, superando os percentuais de variação dos anos anteriores $(16,77 \%$ em $2010,18,72 \%$ em 2009 e 4,57\% em 2008).

No que diz respeito à execução física do orçamento-programa, a partir das respectivas linhas de ação, os valores orçados e realizados comportaram-se tal qual demonstrado na Tabela 11:

Tabela 11 - Execução física do orçamento-programa - Programas de Governo 2011 (Em R\$ mil)

\begin{tabular}{cccccc}
\hline $\begin{array}{c}\text { Programas de } \\
\text { Governo }\end{array}$ & $\begin{array}{c}\text { Autorizado final } \\
(1)\end{array}$ & $\begin{array}{c}\text { AV \% } \\
\text { S/TOTAL }\end{array}$ & Realizado (2) & $\begin{array}{c}\text { AV \% } \\
\text { S/TOTAL }\end{array}$ & $\begin{array}{c}\text { AH \% } \\
2 / 1\end{array}$ \\
\hline $\begin{array}{c}\text { Promoção da } \\
\text { Cidadania, Inclusão } \\
\text { Social e Justiça }\end{array}$ & $\mathbf{9 . 8 5 8 . 0 9 3}$ & $\mathbf{3 7 , 3 1 \%}$ & $\mathbf{9 . 0 5 8 . 9 4 3}$ & $\mathbf{3 6 , 8 3 \%}$ & $\mathbf{9 1 , 8 9 \%}$ \\
\hline $\begin{array}{c}\text { Educação de } \\
\text { Qualidade }\end{array}$ & 4.274 .180 & $16,18 \%$ & 4.113 .068 & $16,72 \%$ & $96,23 \%$ \\
Cultura Paranaense & 95.759 & $0,36 \%$ & 81.385 & $0,33 \%$ & $84,99 \%$ \\
Leite das crianças & 67.785 & $0,26 \%$ & 67.782 & $0,28 \%$ & $99,99 \%$ \\
Saúde e Saneamento & 2.660 .569 & $10,07 \%$ & 2.502 .221 & $10,17 \%$ & $94,05 \%$ \\
Trabalho, Emprego e & 113.816 & $0,43 \%$ & 91.176 & $0,37 \%$ & $79,23 \%$ \\
Assistência Social & 228.813 & $0,87 \%$ & 174.389 & $0,71 \%$ & $76,21 \%$ \\
Habitação Popular & 1.895 .017 & $7,17 \%$ & 1.603 .473 & $6,52 \%$ & $84,62 \%$ \\
Segurança Integrada & 328.770 & $1,24 \%$ & 293.527 & $1,19 \%$ & $89,28 \%$ \\
Promoção da Justiça & & & & &
\end{tabular}




\begin{tabular}{|c|c|c|c|c|c|}
\hline $\begin{array}{c}\text { e Cidadania } \\
\text { Proteção à Criança e } \\
\text { a Juventude }\end{array}$ & 193.383 & $0,73 \%$ & 132.923 & $0,54 \%$ & $68,74 \%$ \\
\hline $\begin{array}{c}\text { Linha de ação } \\
\text { Desenvolvimento } \\
\text { Econômico } \\
\text { Sustentável e } \\
\text { Descentralizado }\end{array}$ & 3.132.117 & $11,85 \%$ & 2.473 .066 & $10,05 \%$ & $78,96 \%$ \\
\hline $\begin{array}{l}\text { Ensino Superior e } \\
\text { Desenvolvimento } \\
\text { Científico- } \\
\text { Tecnológico }\end{array}$ & 1.451 .409 & $5,49 \%$ & 1.256 .287 & $5,11 \%$ & $86,56 \%$ \\
\hline $\begin{array}{l}\text { Transporte } \\
\text { Integrado e Logística } \\
\text { Preservação }\end{array}$ & 915.234 & $3,46 \%$ & 656.113 & $2,67 \%$ & $71,69 \%$ \\
\hline $\begin{array}{c}\text { Ambiental e Gestão } \\
\text { de Recursos Hídricos } \\
\text { Desenvolvimento }\end{array}$ & 228.515 & $0,86 \%$ & 148.758 & $0,60 \%$ & $65,10 \%$ \\
\hline $\begin{array}{l}\text { Regional e } \\
\text { Metropolitano } \\
\text { Diversificação }\end{array}$ & 101.408 & $0,38 \%$ & 84.426 & $0,34 \%$ & $83,25 \%$ \\
\hline $\begin{array}{c}\text { Agropecuária e } \\
\text { Fortalecimento do } \\
\text { Agronegócio Familiar }\end{array}$ & 349.406 & $1,32 \%$ & 267.066 & $1,09 \%$ & $76,43 \%$ \\
\hline $\begin{array}{l}\text { Desenvolvimento da } \\
\text { Produção }\end{array}$ & 46.163 & $0,17 \%$ & 37.885 & $0,15 \%$ & $82,07 \%$ \\
\hline $\begin{array}{c}\text { Turismo, Esporte e } \\
\text { Lazer }\end{array}$ & 39.982 & $0,15 \%$ & 22.531 & $0,09 \%$ & $56,35 \%$ \\
\hline $\begin{array}{l}\text { Linha de ação } \\
\text { Gestão Pública } \\
\text { Transparente e } \\
\text { Integrada }\end{array}$ & 2.826 .961 & $10,70 \%$ & 2.494 .145 & $10,14 \%$ & $88,23 \%$ \\
\hline $\begin{array}{l}\text { Gestão do Estado } \\
\text { Apoio e }\end{array}$ & 682.568 & $2,58 \%$ & 619.486 & $2,52 \%$ & $90,76 \%$ \\
\hline $\begin{array}{l}\text { Desenvolvimento do } \\
\text { Ministério Público }\end{array}$ & 403.233 & $1,53 \%$ & 393.465 & $1,60 \%$ & $97,58 \%$ \\
\hline Ação Legislativa & 259.349 & $0,98 \%$ & 236.669 & $0,96 \%$ & $91,26 \%$ \\
\hline $\begin{array}{c}\text { Controle Externo ao } \\
\text { Estado }\end{array}$ & 178.557 & $0,68 \%$ & 177.521 & $0,72 \%$ & $99,42 \%$ \\
\hline $\begin{array}{l}\text { Ação Judiciária } \\
\text { Valorização e }\end{array}$ & 1.302 .347 & $4,93 \%$ & 1.066 .748 & $4,34 \%$ & $81,91 \%$ \\
\hline $\begin{array}{l}\text { Capacitação do } \\
\text { Servidor Público }\end{array}$ & 906 & $0,00 \%$ & 257 & $0,00 \%$ & $28,34 \%$ \\
\hline Obrigações Especiais & 10.606 .144 & $40,14 \%$ & 10.571.124 & $42,98 \%$ & $99,67 \%$ \\
\hline TOTAL & 26.423.315 & $100,00 \%$ & 24.597.279 & $100,00 \%$ & $93,09 \%$ \\
\hline
\end{tabular}

Fonte: Adaptado da Instrução 92/2012 da Diretoria de Contas Estaduais extraída dos autos 296372/12 TCE/PR; Lei 15.757/07 (PPA), Lei 16.561/10 (LDO) e Lei 16.739/10 (LOA)

Por tratar-se do ano de encerramento do PPA, o relatório do Controle Interno do Governo do Estado apresentou ao TCE/PR os resultados finais dos programas e metas definidas no PPA, compreendendo o período de 2008 a 2011, conforme sintetizados na Tabela 12:

Tabela 12 - Programas e metas definidas no PPA - Resultados finais - 2008 a 2011 


\begin{tabular}{|c|c|c|c|c|c|c|c|c|}
\hline Prog. / indicador & $\begin{array}{c}\text { Unidade } \\
\text { de medida }\end{array}$ & Período & Índice & $\begin{array}{l}\text { Data } \\
\text { apuraç } \\
\text { ão }\end{array}$ & $\begin{array}{c}\text { Índice } \\
\text { desejado } \\
\text { em } 2011\end{array}$ & $\begin{array}{l}\text { Índice } \\
\text { obtido }\end{array}$ & $\begin{array}{l}\text { Índice/ } \\
\text { meta }\end{array}$ & $\begin{array}{c}\text { Sim } \\
\text { /nã } \\
\text { o* }\end{array}$ \\
\hline \multicolumn{9}{|c|}{ Cultura Paranaense } \\
\hline Concursos culturais & $\begin{array}{c}\text { participant } \\
\mathrm{e}\end{array}$ & anual & 18.726 & $\begin{array}{c}30 / 12 / \\
06\end{array}$ & 30.160 & 15.640 & $51.86 \%$ & Não \\
\hline $\begin{array}{l}\text { Espetáculos } \\
\text { produzidos em } \\
\text { equipamentos } \\
\text { culturais }\end{array}$ & espetáculo & anual & 495 & $\begin{array}{c}30 / 12 / \\
06\end{array}$ & 799 & 873 & $\begin{array}{c}109.26 \\
\%\end{array}$ & Sim \\
\hline Visita nos museus & pessoa & anual & 246.100 & $\begin{array}{c}30 / 12 / \\
06\end{array}$ & 363.591 & 446.980 & $\begin{array}{c}122.93 \\
\%\end{array}$ & Sim \\
\hline \multicolumn{9}{|c|}{ Desenvolvimento da Produção } \\
\hline $\begin{array}{l}\text { Participação das } \\
\text { exportações } \\
\text { paranaenses em } \\
\text { relação a exportação } \\
\text { brasileira }\end{array}$ & percentual & anual & $7.3 \%$ & $\begin{array}{c}31 / 12 / \\
06\end{array}$ & $7.3 \%$ & $6.79 \%$ & $93.01 \%$ & Não \\
\hline \multicolumn{9}{|c|}{ Desenvolvimento na Área Energética } \\
\hline $\begin{array}{l}\text { Novos consumidores } \\
\text { urbanos e rurais de } \\
\text { energia elétrica } \\
\text { incluídos }\end{array}$ & unidade & anual & $\begin{array}{c}3.385 .73 \\
8\end{array}$ & $\begin{array}{c}01 / 06 / \\
07\end{array}$ & $\begin{array}{c}3.752 .96 \\
9\end{array}$ & $\begin{array}{c}3.917 .00 \\
0\end{array}$ & $\begin{array}{c}104.37 \\
\%\end{array}$ & Sim \\
\hline \multicolumn{9}{|c|}{ Desenvolvimento Regional e Metropolitano } \\
\hline $\begin{array}{c}\text { Desembolsos do FDU } \\
\text { por área de } \\
\text { investimento } \\
\end{array}$ & milhão R\$ & anual & 150 & $\begin{array}{c}31 / 12 / \\
12 \\
\end{array}$ & 156 & 102 & $65.64 \%$ & Não \\
\hline \multicolumn{9}{|c|}{ Diversificação da Agropecuária e fortalecimento do Agronegócio Familiar } \\
\hline $\begin{array}{l}\text { Produção física de } \\
\text { leite no Estado }\end{array}$ & $\begin{array}{l}\text { Litros/vaca } \\
\text { s/anos }\end{array}$ & anual & 1.800 & $\begin{array}{c}30 / 08 / \\
07\end{array}$ & 4.000 & 2.394 & $59.85 \%$ & Não \\
\hline $\begin{array}{l}\text { Produtores } \\
\text { beneficiados }\end{array}$ & produtor & anual & 215.392 & $\begin{array}{c}31 / 05 / \\
07\end{array}$ & 270.000 & 216.000 & $80.00 \%$ & Não \\
\hline $\begin{array}{l}\text { Produção física de } \\
\text { grãos no Estado }\end{array}$ & tonelada & anual & $\begin{array}{c}29.467 .3 \\
65 \\
\end{array}$ & $\begin{array}{c}20 / 08 / \\
07 \\
\end{array}$ & $\begin{array}{c}36.244 .8 \\
58 \\
\end{array}$ & $\begin{array}{c}31.880 .0 \\
00\end{array}$ & $87.96 \%$ & Não \\
\hline \multicolumn{9}{|c|}{ Educação de Qualidade } \\
\hline Taxa de analfabetismo & percentual & anual & $7.3 \%$ & $\begin{array}{c}31 / 12 / \\
06\end{array}$ & $1.0 \%$ & $6.3 \%$ & $15.87 \%$ & Não \\
\hline \multicolumn{9}{|c|}{ Ensino Superior e Desenvolvimento Científico-Tecnológico } \\
\hline $\begin{array}{l}\text { Variação anual de } \\
\text { concluintes }\end{array}$ & percentual & anual & $74.5 \%$ & $\begin{array}{c}30 / 07 / \\
06\end{array}$ & $84.5 \%$ & $71.5 \%$ & $84.62 \%$ & Não \\
\hline $\begin{array}{c}\text { Percentual de } \\
\text { professores efetivos } \\
\text { com titulação em } \\
\text { doutorado nas - IEES }\end{array}$ & percentual & anual & $39.5 \%$ & $\begin{array}{c}30 / 07 / \\
06\end{array}$ & $49.9 \%$ & $46.0 \%$ & $92.18 \%$ & Não \\
\hline \multicolumn{9}{|c|}{ Habitação Popular } \\
\hline $\begin{array}{c}\text { Número de } \\
\text { beneficiários de novas } \\
\text { habitações no ano }\end{array}$ & pessoa & anual & 8.720 & $\begin{array}{c}31 / 12 / \\
06\end{array}$ & 8.907 & 4.448 & $49.94 \%$ & Não \\
\hline \multicolumn{9}{|c|}{ Leite das Crianças } \\
\hline $\begin{array}{l}\text { Beneficiados pelo } \\
\text { programa }\end{array}$ & $\begin{array}{c}\text { Criança/ } \\
\text { dia }\end{array}$ & mensal & 173.829 & $\begin{array}{c}30 / 08 / \\
07\end{array}$ & 200.000 & 144.238 & $72.12 \%$ & Não \\
\hline $\begin{array}{l}\text { Usinas de } \\
\text { beneficiamento de } \\
\text { leite fornecedoras }\end{array}$ & número & anual & 70 & $\begin{array}{c}30 / 08 / \\
07\end{array}$ & 85 & 67 & $78.82 \%$ & Não \\
\hline
\end{tabular}




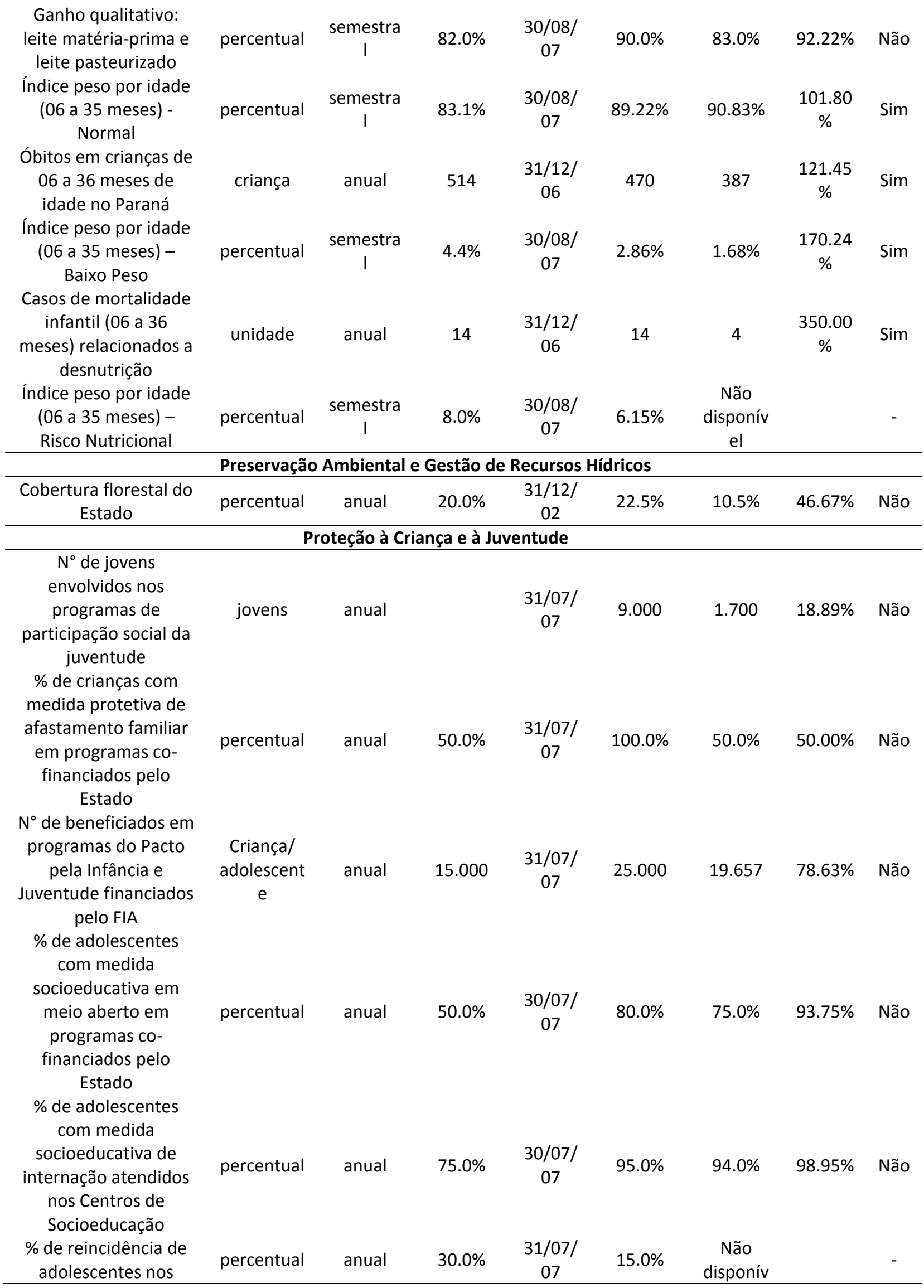

Perspectivas em Gestão \& Conhecimento, João Pessoa, v. 6, n. 2, p. 153-187, jul./dez. 2016. 
Centros de

el

Socioeducação e

ingressos no sistema

penitenciário

\begin{tabular}{|c|c|c|c|c|c|c|c|c|}
\hline \multicolumn{9}{|c|}{ Saúde e Saneamento } \\
\hline $\begin{array}{l}\text { Proporção de óbitos } \\
\text { de mulheres em idade } \\
\text { fértil investigada }\end{array}$ & percentual & anual & $93.0 \%$ & $\begin{array}{c}31 / 12 / \\
06\end{array}$ & $95.0 \%$ & $68.7 \%$ & $72.32 \%$ & Não \\
\hline $\begin{array}{l}\text { Proporção de imóveis } \\
\text { inspecionados para } \\
\text { identificação e } \\
\text { eliminação de } \\
\text { criadouros de Aedes } \\
\text { Aegypti }\end{array}$ & percentual & anual & $84.9 \%$ & $\begin{array}{c}31 / 12 / \\
06\end{array}$ & $80.0 \%$ & $73.8 \%$ & $92.25 \%$ & Não \\
\hline $\begin{array}{c}\text { Proporção de nascidos } \\
\text { vivos com baixo peso } \\
\text { ao nascer }\end{array}$ & percentual & anual & $8.3 \%$ & $\begin{array}{c}31 / 12 / \\
06\end{array}$ & $8.0 \%$ & $8.6 \%$ & $93.02 \%$ & Não \\
\hline $\begin{array}{c}\text { Proporção de } \\
\text { municípios do Estado } \\
\text { com cobertura vacinal } \\
\text { adequada para } \\
\text { tetravalente em } \\
\text { menores de um ano } \\
\text { de idade }\end{array}$ & percentual & Anual & $61.7 \%$ & $\begin{array}{c}31 / 12 / \\
06\end{array}$ & $70.0 \%$ & $74.7 \%$ & $\begin{array}{c}106.71 \\
\%\end{array}$ & Sim \\
\hline $\begin{array}{l}\text { Coeficiente de } \\
\text { mortalidade infantil }\end{array}$ & $\begin{array}{l}\text { Por } 1.000 \\
\text { n.v. }\end{array}$ & anual & 13.7 & $\begin{array}{c}31 / 12 / \\
06\end{array}$ & 12.9 & 11.50 & $\begin{array}{c}112.17 \\
\%\end{array}$ & Sim \\
\hline $\begin{array}{c}\text { Razão de mortalidade } \\
\text { materna }\end{array}$ & $\begin{array}{l}\text { Por } 1.000 \\
\text { n.v. }\end{array}$ & anual & 61.8 & $\begin{array}{c}31 / 12 / \\
06\end{array}$ & 56.8 & 41.20 & $\begin{array}{c}137.86 \\
\%\end{array}$ & Sim \\
\hline \multicolumn{9}{|c|}{ Trabalho, Emprego e Assistência Social } \\
\hline Trabalhador habilitado & unidade & anual & 392.842 & $\begin{array}{c}31 / 12 / \\
06\end{array}$ & 442.546 & 411.309 & $92.94 \%$ & Não \\
\hline $\begin{array}{c}\text { Empregos formais } \\
\text { estimados }\end{array}$ & unidade & anual & 343.788 & $\begin{array}{c}14 / 08 / \\
07\end{array}$ & 109.690 & 145.926 & $\begin{array}{c}133.03 \\
\%\end{array}$ & Sim \\
\hline $\begin{array}{c}\text { Habilitação dos } \\
\text { municípios ao SUAS }\end{array}$ & unidade & $\begin{array}{c}\text { semestra } \\
\text { I }\end{array}$ & 167 & $\begin{array}{c}07 / 08 / \\
07\end{array}$ & 283 & 399 & $\begin{array}{c}140.99 \\
\%\end{array}$ & Sim \\
\hline \multicolumn{9}{|c|}{ Transporte Integrado e Logístisca } \\
\hline $\begin{array}{c}\text { Condição de } \\
\text { trafegabilidade }\end{array}$ & percentual & anual & $90.0 \%$ & $\begin{array}{c}31 / 08 / \\
07\end{array}$ & $90.0 \%$ & $90.0 \%$ & $\begin{array}{c}100.00 \\
\%\end{array}$ & Sim \\
\hline $\begin{array}{l}\text { Movimentação de } \\
\text { cargas }\end{array}$ & toneladas & anual & $\begin{array}{c}32.563 .1 \\
70\end{array}$ & $\begin{array}{l}\text { Sem } \\
\text { inform } \\
\text { ação }\end{array}$ & $\begin{array}{c}37.432 .0 \\
00\end{array}$ & $\begin{array}{c}41.061 .3 \\
39\end{array}$ & $\begin{array}{c}109.70 \\
\%\end{array}$ & Sim \\
\hline \multicolumn{9}{|c|}{ Turismo, Esporte e Lazer } \\
\hline $\begin{array}{c}\text { Permanência média do } \\
\text { visitante }\end{array}$ & dia & anual & 3 & $\begin{array}{c}31 / 12 / \\
06\end{array}$ & 5 & 4 & $80.00 \%$ & Não \\
\hline $\begin{array}{c}\text { Participantes nos } \\
\text { Jogos Abertos Paraná } \\
\text { e Juventude }\end{array}$ & atleta & anual & 29.204 & $\begin{array}{c}31 / 12 / \\
06\end{array}$ & 31.000 & 28.593 & $92.24 \%$ & Não \\
\hline $\begin{array}{c}\text { Destino } \\
\text { comercializado destino }\end{array}$ & destino & anual & 60 & $\begin{array}{c}31 / 12 / \\
06\end{array}$ & 80 & 80 & $\begin{array}{c}100.00 \\
\%\end{array}$ & Sim \\
\hline $\begin{array}{l}\text { Gasto médio do } \\
\text { visitante }\end{array}$ & US\$/dia & anual & 60 & $\begin{array}{c}31 / 12 / \\
06\end{array}$ & 70 & 73 & $\begin{array}{c}103.57 \\
\%\end{array}$ & Sim \\
\hline Número de visitantes & visitantes & anual & $\begin{array}{c}7.300 .00 \\
0\end{array}$ & $\begin{array}{c}31 / 12 / \\
06\end{array}$ & $\begin{array}{c}9.000 .00 \\
0\end{array}$ & $\begin{array}{c}13.213 .7 \\
13\end{array}$ & $\begin{array}{c}146.82 \\
\%\end{array}$ & Sim \\
\hline Equipamentos e & unidade & anual & 468 & $31 / 12 /$ & 700 & 3.155 & 450.71 & Sim \\
\hline
\end{tabular}

Perspectivas em Gestão \& Conhecimento, João Pessoa, v. 6, n. 2, p. 153-187, jul./dez. 2016. 
profissionais

06

$\%$ cadastrados unidade Valorização e Capacitação do Servidor Público

\begin{tabular}{ccccccccc}
\multicolumn{10}{c}{ Valorização e Capacitação do Servidor Público } \\
\hline $\begin{array}{c}\text { Capacitar agentes } \\
\text { públicos }\end{array}$ & Servidor & anual & 5.319 & $\begin{array}{c}31 / 12 / \\
06\end{array}$ & 10.000 & 7.055 & $70.55 \%$ & Não \\
$\begin{array}{c}\text { Cursos para agentes } \\
\text { públicos }\end{array}$ & curso & anual & 131 & $\begin{array}{c}31 / 12 / \\
06\end{array}$ & 188 & 173 & $92.02 \%$ & Não \\
\hline
\end{tabular}

* Sim = alcançou a meta / não = não alcançou a meta

Fonte: Adaptado da Instrução 92/2012 da Diretoria de Contas Estaduais extraída dos autos 296372/12 TCE/PR

Diante das informações e dados apresentados pelo Governo do Estado, o TCE/PR, no acórdão 290/12, pondera que o planejamento estadual se mostra deficiente, haja vista o grande percentual de alteração do orçamento $(42,57 \%$ de créditos adicionais, equivalente a $R \$$ 10,8 bilhões e $38,15 \%$ de cancelamentos, equivalente a $R \$ 9,7$ bilhões). Assevera que tal deficiência encontra complacência do Poder Legislativo já que este autoriza a abertura do significativo volume de créditos.

Ao final, em alinhamento ao objeto deste estudo, determinou-se que o Governo do Estado promova um planejamento adequado das obras programadas e as execute conforme previsto e desenvolva, em 180 dias, um sistema de execução e fiscalização de obras públicas, cujo sistema deverá ser acessível ao controle externo e possuir mecanismo que correlacione as obras ao acompanhamento e execução dos programas previstos no PPA.

\subsection{Prestação de contas Estadual - Exercício financeiro de 2012}

A prestação de contas estadual referente ao exercício financeiro de 2012, encaminhada ao TCE/PR pela Assembleia Legislativa do Estado do Paraná (ALEP) em 02 de abril de 2012, foi autuada em processo sob o número 210041/13, o qual, em cumprimento ao rito processual, foi distribuído ao Conselheiro Relator para os devidos encaminhamentos. Após a relatoria, em plenário o Tribunal Pleno, por meio do Acórdão 306/13, emitiu, por unanimidade, parecer prévio pela aprovação das contas com ressalvas.

Insta pontuar que se trata do primeiro ano do PPA 2012-2015, o qual, segundo notas constantes na Instrução 69/13 da Diretoria de Contas Estaduais do TCE/PR, foi elaborado a partir da influência do planejamento estratégico abraçado pela União para estruturação do seu PPA. A proposta do PPA estadual incorporou orientações do Governo Federal adaptada a realidade do Estado, visando uma roupagem mais estratégica para viabilizar a formulação, a gestão e a implementação das políticas públicas.

Os Programas de Governo foram agrupados, neste PPA 2012-2015, em três linhas mestras: i) Programas Finalísticos; ii) Programas de Gestão, Manutenção e Serviços ao Estado; e iii) Obrigações Especiais.

A Instrução 69/13-DCE trouxe o comparativo entre a previsão de Orçamento dos Programas de Governo no PPA e o que foi de fato contemplado na LOA-2012, tal qual demonstra a Tabela 13:

Tabela 13 - Comparativo do Orçamento 2012 - PPA x LOA (Em R\$ milhão)

Programas de Governo PPA (1) Lei orçamentária Variação AH \%

$$
\text { Final (3) }
$$

considerando os

Inicial (2) 


\begin{tabular}{|c|c|c|c|c|c|}
\hline \multicolumn{6}{|c|}{ Programas Finalísticos } \\
\hline Acesso à Justiça & 47.000 & 50.000 & 42.450 & 6,38 & $-9,68$ \\
\hline $\begin{array}{l}\text { Desenvolvimento das } \\
\text { Cidades }\end{array}$ & 238.521 & 250.559 & 192.052 & 5,05 & $-19,48$ \\
\hline $\begin{array}{c}\text { Desenvolvimento } \\
\text { Integrado da Cidadania }\end{array}$ & 341.583 & 341.583 & 330.320 & 0,00 & $-3,30$ \\
\hline $\begin{array}{l}\text { Desenvolvimento Rural } \\
\text { Sustentável e } \\
\text { Abastecimento }\end{array}$ & 396.786 & 373.662 & 409.479 & $-5,83$ & 3,20 \\
\hline $\begin{array}{l}\text { Desenvolvimento } \\
\text { Sustentável do Turismo }\end{array}$ & 6.958 & 6.958 & 12.017 & 0,00 & 72,71 \\
\hline Educação para todos & 543.400 & 555.270 & 603.437 & 2,18 & 11,05 \\
\hline $\begin{array}{l}\text { Excelência no Ensino } \\
\text { Superior }\end{array}$ & 1.346 .570 & 1.346 .570 & 1.429 .660 & 0,00 & 6,17 \\
\hline Inova Educação & 4.076 .908 & 4.076 .908 & 4.197 .057 & 0,00 & 2,95 \\
\hline Morar Bem Paraná & 552.845 & 551.341 & 198.474 & $-0,27$ & $-64,10$ \\
\hline Paraná Competitivo & 86.788 & 75.023 & 52.098 & $-13,56$ & $-39,97$ \\
\hline Paraná Inovador & 205.003 & 205.003 & 263.842 & 0,00 & 28,70 \\
\hline Paraná Seguro & 2.171.241 & 2.176 .056 & 2.346 .709 & 0,22 & 8,08 \\
\hline Paraná Sustentável & 70.020 & 70.020 & 129.306 & 0,00 & 84,67 \\
\hline Paraná tem Cultura & 13.365 & 13.365 & 19.229 & 0,00 & 43,87 \\
\hline $\begin{array}{c}\text { Paraná: Esporte, Lazer e } \\
\text { Atividade Física }\end{array}$ & 19.482 & 36.322 & 44.350 & 86,44 & 127,65 \\
\hline $\begin{array}{c}\text { Proteção e } \\
\text { Desenvolvimento Social }\end{array}$ & 268.804 & 269.099 & 220.021 & 0,11 & $-18,15$ \\
\hline $\begin{array}{l}\text { Rede Paraná Multimodal } \\
\text { de Transporte e Logística }\end{array}$ & 567.865 & 558.995 & 719.488 & $-1,56$ & 26,70 \\
\hline $\begin{array}{c}\text { Saúde para Todo Paraná } \\
\text { Trabalho, Emprego e }\end{array}$ & 2.819 .604 & 2.843.799 & 2.895 .291 & 0,86 & 2,68 \\
\hline $\begin{array}{l}\text { Empreendimento } \\
\text { Solidários }\end{array}$ & 124.438 & 124.438 & 47.246 & 0,00 & $-62,03$ \\
\hline $\begin{array}{l}\text { Universalização do } \\
\text { Saneamento Básico }\end{array}$ & 580.487 & 19.068 & 1.004 & $-96,72$ & $-99,83$ \\
\hline \multicolumn{6}{|c|}{ Programas de Gestão, Manutenção e Serviços ao Estado } \\
\hline Gestão Estratégica & 808.777 & 796.574 & 1.010 .566 & $-1,51$ & 24,95 \\
\hline Gestão Administrativa & 950.338 & 981.393 & 1.203 .471 & 3,27 & 26,64 \\
\hline Gestão de Serviços & 186.662 & 186.662 & 218.974 & 0,00 & 17,31 \\
\hline $\begin{array}{c}\text { Gestão Institucional - } \\
\text { Outros Poderes e } \\
\text { Ministério Público }\end{array}$ & 2.278 .783 & 2.278 .783 & 2.689 .286 & 0,00 & 18,01 \\
\hline \multicolumn{6}{|c|}{ Programas de Obrigações Especiais } \\
\hline Obrigações Especiais & 11.608 .043 & 11.500 .055 & 11.946 .207 & $-0,93$ & 2,91 \\
\hline TOTAL & 30.310 .270 & 29.687 .505 & 31.222 .036 & $-2,05$ & 3,01 \\
\hline
\end{tabular}

Nota: Não está incluído o valor do Orçamento de Investimento das Empresas Públicas e Sociedades de Economia Mista Dependentes.

Fonte: Adaptado da Instrução 69/2013 da Diretoria de Contas Estaduais extraída dos autos 210041/13 TCE/PR; Lei 16.889/11 (LDO) e Lei 17.012/11 (LOA)

Verifica-se na análise da tabela 13 que o total orçamentário final autorizado na LOA para o exercício de 2012 apresenta um acréscimo de 3,01\% em relação ao previsto no PPA, valor expressivamente inferior às variações apresentadas nos anos anteriores $(25,34 \% \mathrm{em}$ $2011,16,67 \%$ em 2010, 18,72\% em 2009), aproximando-se apenas da variação de 4,57\% constatada em 2008, coincidência ou não, referem-se aos primeiros anos de efetiva execução 
do PPA por parte do governo que o elaborou, fato que, em princípio não justificaria a adoção de créditos adicionais, conforme referenciado pelo TCE quanto à execução total do PPA anterior.

A Tabela 14 demonstra os valores orçados e realizados nos Programas de Governo para o exercício de 2012:

Tabela 14 - Execução física do orçamento-programa - Programas de Governo 2012 (Em R\$ mil)

\begin{tabular}{|c|c|c|c|c|c|}
\hline $\begin{array}{c}\text { Programas de } \\
\text { Governo }\end{array}$ & $\begin{array}{c}\text { Autorizado final } \\
(1)\end{array}$ & $\begin{array}{c}\text { AV \% } \\
\text { S/TOTAL }\end{array}$ & Realizado (2) & $\begin{array}{c}\text { AV \% } \\
\text { S/TOTAL }\end{array}$ & $\begin{array}{c}\mathrm{AH} \% \\
2 / 1 \\
\end{array}$ \\
\hline $\begin{array}{l}\text { Programas } \\
\text { Finalísticos } \\
\end{array}$ & 14.153.531 & $23,11 \%$ & 12.488 .026 & $43,83 \%$ & $88,23 \%$ \\
\hline Acesso à Justiça & 42.450 & $0,148 \%$ & 23.885 & $0,08 \%$ & $56,27 \%$ \\
\hline $\begin{array}{l}\text { Desenvolvimento } \\
\text { das Cidades }\end{array}$ & 192.052 & $0,62 \%$ & 80.861 & $0,28 \%$ & $42,10 \%$ \\
\hline $\begin{array}{l}\text { Desenvolvimento } \\
\text { Integrado da } \\
\text { Cidadania }\end{array}$ & 330.320 & $1,06 \%$ & 318.308 & $1,12 \%$ & $96,36 \%$ \\
\hline $\begin{array}{l}\text { Desenvolvimento } \\
\text { Rural Sustentável e } \\
\text { Abastecimento }\end{array}$ & 409.479 & $1,31 \%$ & 312.965 & $1,10 \%$ & $76,43 \%$ \\
\hline $\begin{array}{c}\text { Desenvolvimento } \\
\text { Sustentável do } \\
\text { Turismo }\end{array}$ & 12.017 & $0,04 \%$ & 2.836 & $0,01 \%$ & $23,60 \%$ \\
\hline Educação para todos & 603.437 & $1,93 \%$ & 561.655 & $1,07 \%$ & $93,08 \%$ \\
\hline $\begin{array}{l}\text { Excelência no Ensino } \\
\text { Superior }\end{array}$ & 1.429 .660 & $4,58 \%$ & 1.230 .314 & $4,32 \%$ & $86,06 \%$ \\
\hline Inova Educação & 4.197.057 & $13,44 \%$ & 4.145.349 & $14,55 \%$ & $98,77 \%$ \\
\hline Morar Bem Paraná & 198.474 & $0,64 \%$ & 129.630 & $0,45 \%$ & $65,31 \%$ \\
\hline Paraná Competitivo & 52.098 & $0,17 \%$ & 41.175 & $0,14 \%$ & $79,03 \%$ \\
\hline Paraná Inovador & 263.842 & $0,85 \%$ & 213.030 & $0,75 \%$ & $80,74 \%$ \\
\hline Paraná Seguro & 2.346 .709 & $7,52 \%$ & 1.985 .698 & $6,97 \%$ & $84,62 \%$ \\
\hline Paraná Sustentável & 129.306 & $0,41 \%$ & 89.704 & $0,31 \%$ & $69,37 \%$ \\
\hline $\begin{array}{c}\text { Paraná tem Cultura } \\
\text { Paraná: Esporte, }\end{array}$ & 19.229 & $0,06 \%$ & 17.633 & $0,06 \%$ & $91,70 \%$ \\
\hline $\begin{array}{c}\text { Lazer e Atividade } \\
\text { Física } \\
\text { Proteção e }\end{array}$ & 44.350 & $0,14 \%$ & 28.585 & $0,10 \%$ & $64,45 \%$ \\
\hline $\begin{array}{c}\text { Desenvolvimento } \\
\text { Social }\end{array}$ & 220.021 & $0,70 \%$ & 91.101 & $0,32 \%$ & $41,41 \%$ \\
\hline $\begin{array}{l}\text { Rede Paraná } \\
\text { Multimodal de } \\
\text { Transporte e } \\
\text { Logística }\end{array}$ & 719.488 & $2,30 \%$ & 430.385 & $1,51 \%$ & $59,82 \%$ \\
\hline $\begin{array}{c}\text { Saúde para Todo } \\
\text { Paraná } \\
\text { Trabalho, Emprego e }\end{array}$ & 2.895 .291 & $9,27 \%$ & 2.762 .265 & $9,70 \%$ & $95,41 \%$ \\
\hline $\begin{array}{l}\text { Empreendimento } \\
\text { Solidários }\end{array}$ & 47.246 & $0,15 \%$ & 21.742 & $0,08 \%$ & $46,02 \%$ \\
\hline $\begin{array}{l}\text { Universalização do } \\
\text { Saneamento Básico }\end{array}$ & 1.004 & $0,00 \%$ & 904 & $0,00 \%$ & $90,04 \%$ \\
\hline $\begin{array}{l}\text { Programa de gestão, } \\
\text { Manutenção e } \\
\text { Serviços ao Estado }\end{array}$ & 5.122 .298 & $16,41 \%$ & 4.566 .000 & $16,03 \%$ & $89,14 \%$ \\
\hline Gestão Estratégica & 1.010 .566 & $3,24 \%$ & 811.875 & $2,85 \%$ & $80,34 \%$ \\
\hline
\end{tabular}

Perspectivas em Gestão \& Conhecimento, João Pessoa, v. 6, n. 2, p. 153-187, jul./dez. 2016. 


\begin{tabular}{|c|c|c|c|c|c|}
\hline $\begin{array}{c}\text { Gestão } \\
\text { Administrativa }\end{array}$ & 1.203 .471 & $3,85 \%$ & 1.107.207 & $3,89 \%$ & $92,00 \%$ \\
\hline $\begin{array}{l}\text { Gestão de Serviços } \\
\text { Gestão Institucional }\end{array}$ & 218.974 & $0,70 \%$ & 203.841 & $0,72 \%$ & $93,09 \%$ \\
\hline $\begin{array}{l}\text { - Outros Poderes e } \\
\text { Ministério Público }\end{array}$ & 2.689 .286 & $8,61 \%$ & 2.443 .076 & $8,58 \%$ & $90,84 \%$ \\
\hline $\begin{array}{c}\text { Programa de } \\
\text { Obrigações Especiais }\end{array}$ & 11.946 .207 & $38,26 \%$ & 11.436 .657 & $40,14 \%$ & $95,73 \%$ \\
\hline TOTAL & 31.222 .036 & $100,00 \%$ & 28.490 .682 & $100,00 \%$ & $91,25 \%$ \\
\hline
\end{tabular}

Fontes: Adaptado da Instrução 69/2013 da Diretoria de Contas Estaduais extraída dos autos 210041/13 TCE/PR; Lei 17.013/11 (PPA), Lei 16.889/11 (LDO) e Lei 17.012/11 (LOA)

Os cinco programas de maior expressão (Obrigações Especiais: 40,14\%; Inova Educação: 14,55\%; Saúde para Todo Paraná: 9,70\%; Gestão Institucional - Outros Poderes e Ministério Público: 8,58\%; e Paraná Seguro: 6,97\%), representaram 79,93\% de realização do Orçamento Geral do Estado em 2012, totalizando R\$ 28,5 bilhões. Os programas de governo restantes responderam por $20,07 \%$ de realização, equivalente a $R \$ 5,7$ bilhões.

Nos fundamentos do acórdão 290/12, lastreado nos achados da Instrução 69/13-DCE, destacou-se como relevante no curso da prestação de contas do exercício de 2012, que o Sistema de Controle Interno foi finalmente implantado, demonstrando efetividade, destacando também que as recomendações, ressalvas e determinações dos exercícios anteriores ainda precisam ser implementadas pela Administração Estadual.

Constatou-se, ainda, que o PPA 2012-2015 não individualiza investimento e custeio e, embora esteja disponível na internet como documento público que é, sua formatação dificulta consultas e análises personalizadas, tornando opaca a transparência, especialmente pelo fato de que o detalhamento dos programas não é uniforme. $O$ acórdão aponta também que a execução das obras previstas na LOA 2012 atingiram apenas 31\% do valor previsto, ficando bastante inferior ao planejado no orçamento.

Neste diapasão o TCE/PR reiterou as recomendações dos anos anteriores para que o Governo Estadual desenvolva com a máxima brevidade um sistema integrado e informatizado de controle de execução e fiscalização de obras públicas que viabilize uma visão ampla e segura da execução das obras seja acessível não apenas ao Controle Externo, mas também ao controle social.

Outra recomendação pertinente, não obstante ser ainda o primeiro ano de execução de seu próprio PPA, advém da constatação de que são excessivas as modificações orçamentárias a partir da abertura de créditos adicionais o que dificulta o controle pelo TCE/PR e pela sociedade da execução anual. Diante disso, recomendou-se um exame atento da metodologia de planejamento do Governo, para que se construa um orçamento mais estável durante o exercício financeiro.

\section{CONCLUSÃO}

A pesquisa buscou verificar o comportamento da avaliação e controle do PPA do Governo do Estado do Paraná no período de 2007 a 2012 sob a ótica do TCE/PR, com o fito de conhecer como se comporta a execução orçamentária estadual frente às ações e programas traçados no PPA e, também, de responder se as determinações e recomendações do controle externo, a partir da análise da execução do PPA, são acatadas pelo governo do Paraná.

Do aporte teórico foi possível apreender que toda ação de Governo encontra-se estruturada em programas que são delineados no PPA para um período de quatro anos. Os

Perspectivas em Gestão \& Conhecimento, João Pessoa, v. 6, n. 2, p. 153-187, jul./dez. 2016. 
programas são de essencial importância já que se comportam como o elo entre planejamento e orçamento.

Entrementes para que a interação seja profícua e efetiva, a avaliação de desempenho da ação governamental é mecanismo de importância ímpar e indispensável para construir uma gestão pública pautada nos princípios constitucionais que, em especial, possibilite ao cidadão, acionista maior do estado (shareholder), exercer o controle social, seja ele na forma direta, ou mesmo indireta por meio do parlamento.

Frente a essas considerações e após a verificação dos acórdãos e instruções da DCE, como resultado foi possível identificar que, mesmo a despeito das recomendações e determinações da Corte de Contas quanto à falta de efetividade do Controle Interno e a constante disparidade entre a execução orçamentária anual e as metas e objetivos traçados no Plano Plurianual, o Governo do Estado do Paraná demonstra dificuldade em acatar as determinações e recomendações do controle externo e, por conseguinte, deixa de executar o Plano Plurianual nos moldes planejados.

Verifica-se, ainda, que em grande parte das vezes, o descumprimento não se encontra devidamente justificado, o que se percebe pela constante reiteração de determinações e recomendações da Corte de Contas Estadual.

Nota-se que apenas no ano de 2012, após reiteradas determinações/recomendações do TCE/PR, acerca da inefetividade do Sistema de Controle Interno, este foi finalmente implantado no Governo do Estado, demonstrando, embora tenha repisado pela Corte de Contas que as demais recomendações, ressalvas e determinações dos exercícios anteriores ainda precisam ser implementadas pela Administração Estadual.

Verificou-se, ainda, que o descompasso entre planejamento e execução não logrou força para que o Tribunal desaprovasse qualquer das contas anuais por essa razão, o que evidencia que a falta de congruência ainda é tratada com complacência pelo controle externo.

Desse modo, é possível assentir que os objetivos propostos no presente trabalho foram alcançados, pois essas constatações proporcionaram a resposta para a questão norteadora do estudo, qual seja, as determinações e recomendações exaradas pelo controle externo não foram acatadas a contento nos exercícios analisados.

Outrossim, constatou-se que estudos e pesquisas sobre essa abordagem são escassos no âmbito acadêmico, motivo pelo qual se sugere, complementarmente a este, a realização de outras investigações que visem verificar empiricamente em que medida o planejamento corresponde à execução orçamentária anual e se eventuais determinações exaradas pelo Controle Externo, ou até mesmo Interno, são acatadas pelo Poder Executivo, estudo que pode se estender as esferas federal, outros estados federados e municipal.

Averiguações de tal ordem mostram-se prospectivas, pois poderão contribuir para identificar as deficiências práticas atinentes ao planejamento e orçamento, elementos indispensáveis ao desenvolvimento do país, bem como poderão fornecer ao campo teórico fundamentos para aprimorar as teorias às voltas da temática.

Assim, investigações que busquem aprofundar as justificativas apresentadas pelo Poder Executivo ou motivos da falta das mesmas quando a execução orçamentária não corresponde às metas e objetivos traçados no PPA, parece ser uma boa proposta de pesquisa futuras.

Perspectivas em Gestão \& Conhecimento, João Pessoa, v. 6, n. 2, p. 153-187, jul./dez. 2016. 


\section{REFERÊNCIAS}

ASSIS, L. G. B. de. Processo legislativo e orçamento público: função de controle do parlamento. São Paulo: Saraiva, 2012.

ABRUCIO, F. L. Reforma do Estado no federalismo brasileiro: a situação das administrações públicas estaduais. Revista de Administração Pública, Rio de Janeiro, v. 39, n. 2, p. 40-422, mar./abr. 2005.

BRASIL. Constituição (1988). Diário Oficial da República Federativa do Brasil, Brasília, DF, 05 out. 1988 , p. 1.

Decreto Lei n.o 200, de 25 de fevereiro de 1967. Dispõe sobre a organização da Administração Federal, estabelece diretrizes para a Reforma Administrativa e dá outras providências. Diário Oficial da República Federativa do Brasil, Brasília, DF, 27 mar. 1967.

. Decreto n. 0 2.829, de 29 de outubro de 1998. Estabelece normas para a elaboração e execução do Plano Plurianual e dos Orçamentos da União, e dá outras providências. Diário Oficial da República Federativa do Brasil, Brasília, DF, 30 out. 1998, p. 9.

. Decreto n. 6.601 , de 10 de outubro de 2008. Dispõe sobre a gestão do Plano Plurianual 2008-2011 e de seus programas. 2008. Diário Oficial da República Federativa do Brasil, Brasília, DF, 13 out. 2008, p. 3.

. Lei Complementar n.o 101, de 04 de maio de 2000. Estabelece normas de finanças públicas voltadas para a responsabilidade na gestão fiscal e dá outras providências. Diário Oficial da República Federativa do Brasil, Brasília, DF, 05 mai. 2000, p. 1.

Ministério do planejamento, orçamento e gestão. Guia de Monitoramento PPA 2012-2015: Módulo de Monitoramento. Brasília, DF, 2012.

Ministério do planejamento, orçamento e gestão. Portaria n.o 42, de 14 de abril de 1999. Atualiza a discriminação da despesa por funções. Diário Oficial da República Federativa do Brasil, Brasília, DF, 15 abr. 1999.

CALMON, K. M. N.; GUSSO, D. A. A experiência de avaliação do Plano Plurianual (PPA) do governo federal no Brasil. Planejamento e Políticas Públicas, Brasília, n. 25, 2002.

CAVALCANTE, P. L. Orçamento por Desempenho: uma análise qualitativa comparada dos modelos de avaliação dos programas governamentais no Brasil e nos Estados Unidos. Revista de Gestão, São Paulo, v. 17, n. 1, p. 13-25, jan./mar. 2010.

GARCES, A.; SILVERIA, J. P.. Gestão pública orientada para resultados no Brasil. Revista do Serviço Público, Brasília, ano 53, n. 4, p. 53-77, out./dez. 2002.

GIACOMONI, J. Orçamento Público. 16 ed. São Paulo: Atlas, 2012.

GIL, A. C. Como elaborar projetos de pesquisa. 4. ed. São Paulo: Atlas, 2002.

GODOY, A. S. Pesquisa qualitativa: tipos fundamentais. Revista de Administração de Empresas, São Paulo, v. 35, n.3, p. 20-29, mai/jun. 1995.

LIMA, L. H. Controle Externo. 2. ed. São Paulo: Elsevier, 2008.

MARINI, C. Um decálogo da boa gestão pública: os desafios de um Estado para resultados. In: CONGRESSO do CENTRO LANTINOAMERICANO DE ADMINISTRACIÓN PARA EL DESARROLLO, 13, 2008, Buenos Aires. Anais... Buenos Aires, 2008. Disponível em: http://www.governomatricial.com.br/novo-site-din/publix/publicacoes/publicacao 12-072011 16-37-41Artigo.pdf. Acesso em: 18 set. 2013. 
MILESKI, H. S. O controle da Gestão Pública. São Paulo: Revista dos Tribunais, 2003.

NUNES, S. P. P.; NUNES, R. da C. O processo orçamentário na Lei de Responsabilidade Fiscal: instrumento de planejamento. In: Administração pública: direito administrativo, financeiro e gestão pública: práticas, inovações e polêmicas. Recife: Revista dos Tribunais, 2002.

PARANÁ (Estado). Lei n.o 9.882, de 26 de dezembro de 1991. Aprova o Plano Plurianual para o período de 1992 a 1995. Diário Oficial, Curitiba, PR, 27 dez. 1991, n. 3369.

. Lei n.o 11.306, de 28 de dezembro de 1995. Aprova o Plano Plurianual para o período de 1996 a 1999. Diário Oficial, Curitiba, PR, 29 dez. 1995, n. 4664.

. Lei n.o 12.824, de 28 de dezembro de 1999. Aprova o Plano Plurianual para o período de 2000 a 2003. Diário Oficial, Curitiba, PR, 29 dez. 1999, n. 5649.

. Lei n.o 14.276, de 29 de dezembro de 2003. Aprova o Plano Plurianual para o período de 2004 a 2007. Diário Oficial, Curitiba, PR, 30 dez. 2003, n. 6636.

Lei Complementar n. 113, de 15 de dezembro de 2005. Dispõe sobre a Lei Orgânica do Tribunal de Contas do Estado do Paraná. Diário Oficial, Curitiba, PR, 15 dez. 2005, n. 7123.

. Lei n.o 15.524, de 05 de junho de junho de 2007. Institui o Sistema de Controle Interno do Poder Executivo Estadual, conforme especifica e adota outras providências. Diário Oficial, Curitiba, PR, 05 jun. 2007, n. 7486.

. Lei n. 15.757, de 27 de dezembro de 2007. Aprova o Plano Plurianual para o período de 2008 a 2011. Diário Oficial, Curitiba, PR, 27 dez. 2007, n. 7627.

. Decreto n.o 3.386, de 01 de dezembro de 2011. Regulamenta o Sistema de Controle Interno, conforme artigos 1ㅇ e 70 da Lei no 15.524/2007 e dá outras providências. Diário Oficial, Curitiba, PR, 01 dez. 2011, n. 8600.

. Lei no 17.013, de 14 de dezembro de 2011. Aprova o Plano Plurianual ara o período de 2012 a 2015. Diário Oficial, Curitiba, PR, 14 dez. 2011, n. 8609.

Relatório do Controle Interno: Poder Executivo. Curitiba, PR, 2011. Disponível em: http://www.controleinterno.pr.gov.br/arquivos/File/relatoriocontroleinterno .pdf. Acesso em: 18 set. 2013.

Secretaria de estado do planejamento e coordenação geral. Relatório de Acompanhamento do Plano Plurianual 2012-2015. Curitiba, PR, 2012. Disponível em: http://www.sepl.pr.gov.br/arquivos/File/Arquivos\%20PDF\%20/PPA 2012 2015/Relatorio aco mpanhamento PPA 2012Indicadores e Metas.pdf. Acesso em: 11 set. 2013.

. Tribunal de Contas do Estado. Instrução no 53/2008 da Diretoria de Contas Estadual. Peça integrante dos autos de prestação de contas no 231180/08.

. Tribunal de Contas do Estado. Instrução no 56/2010 da Diretoria de Contas Estadual. Peça integrante dos autos de prestação de contas no 210543/10.

. Tribunal de Contas do Estado. Instrução no 80/2011 da Diretoria de Contas Estadual. Peça integrante dos autos de prestação de contas no 327290/11.

. Tribunal de Contas do Estado. Instrução no 80/2011 da Diretoria de Contas Estadual. Peça integrante dos autos de prestação de contas no 296372/12.

. Tribunal de Contas do Estado. Instrução no 69/2013 da Diretoria de Contas Estadual. Peça integrante dos autos de prestação de contas no 210041/13.

Perspectivas em Gestão \& Conhecimento, João Pessoa, v. 6, n. 2, p. 153-187, jul./dez. 2016. 
Tribunal de Contas do Estado. Prestação de Contas do Governador do Estado no 231180/08. Exercício financeiro de 2007. (Acórdão 1133/08-Tribunal Pleno). Interessado: Roberto Requião de Mello e Silva. Relator: Conselheiro Heinz Georg Herwig. Diário Atos Oficiais do Tribunal de Contas, Curitiba, n. 163, 22 ago. 2008.

- Tribunal de Contas do Estado. Prestação de Contas do Governador do Estado no 179832/09. Exercício financeiro de 2008. (Acórdão 800/09-Tribunal Pleno). Interessado: Roberto Requião de Mello e Silva. Relator: Conselheiro Caio Marcio Nogueira Soares. Diário Atos Oficiais do Tribunal de Contas, Curitiba, n. 220, 09 out. 2009.

. Tribunal de Contas do Estado. Prestação de Contas do Governador do Estado no 210543/10. Exercício financeiro de 2009. (Acórdão 2305/10-Tribunal Pleno). Interessado: Roberto Requião de Mello e Silva. Relator: Conselheiro Fernando Augusto Mello Guimarães. Diário Atos Oficiais do Tribunal de Contas, Curitiba, n. 268, 24 set. 2010.

. Tribunal de Contas do Estado. Prestação de Contas do Governador do Estado no 327290/11. Exercício financeiro de 2010. (Acórdão 176/11-Tribunal Pleno). Interessado: Roberto Requião de Mello e Silva. Relator: Conselheiro Artagão de Mattos Leão. Diário Atos Oficiais do Tribunal de Contas, Curitiba, n. 316, p. 14, 12 set. 2011.

. Tribunal de Contas do Estado. Prestação de Contas do Governador do Estado no 296372/12. Exercício financeiro de 2011. (Acórdão 290/12-Tribunal Pleno). Interessado: Carlos Alberto Richa. Relator: Conselheiro Hermas Eurides Brandão. Diário Atos Oficiais do Tribunal de Contas, Curitiba, n. 466, p. 4, 15 ago. 2012.

. Tribunal de Contas do Estado. Prestação de Contas do Governador do Estado no 210041/13. Exercício financeiro de 2012. (Acórdão 306/13-Tribunal Pleno). Interessado: Carlos Alberto Richa. Relator: Conselheiro Nestor Baptista. Diário Atos Oficiais do Tribunal de Contas, Curitiba, n. 715, p. 18, 30 ago. 2013.

PAULO, L. F. A. O PPA como instrumento de planejamento e gestão estratégica. Revista do Serviço Público, Brasília, v. 61, n. 2, p. 171-187, abr./jun. 2010.

REZENDE, F. Planejamento no Brasil: auge, declínio e caminhos para a reconstrução. Texto para discussão: IPEA, Rio de Janeiro, n. 1522, 2010.

Artigo recebido em 28/01/2014 e aceito para publicação em 11/04/2016 